Vol.16, No. 60, July 2021, 626-649

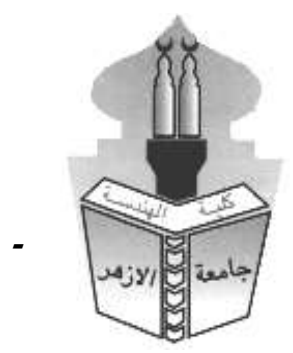

\title{
NUMERICAL STUDY ON THE BEHAVIOR OF RC BEAMS WITH OPENINGS STRENGTHENED WITH ULTRA HIGH PERFORMANCE - FIBER REINFORCED CONCRETE (UHP-FRC)
}

\author{
Mohamed Kassem Elsamny ${ }^{1}$, Mohamed kamel abd-elhamed ${ }^{1}$, Mahmoud Hassan Mahmoud ${ }^{1,}$ Ramadan \\ Saber abd-Elrahman ${ }^{2, *}$ \\ ${ }^{1}$ Civil Engineering Department, Faculty of Engineering, Al-Azhar University, Cairo, Egypt. \\ ${ }^{2}$ Civil Engineering Department, Delta Higher Institute for Engineering and Technology, Mansura, Egypt. \\ *Corresponding Author E-mail: ramadansaber29 @ gmail.com
}

- ABSTRACT

Ultra high performance- Fiber reinforced concrete (UHP-FRC) is a newly developed building material that has major advantages in terms of high strain ability and high compressive and tensile strength, which is useful for strengthening or repairing concrete members. Web openings are usually constructed in simple reinforced concrete (RC) beams in the shear zones that occasionally demand the crossing of water or sewage pipes and utility cables to accommodate the utility. The presence of opening has a remarkable effect on the ultimate strength of (RC) beams and the beams failed due to shear. This research analyzes numerically simple RC beams with opening strengthening using a UHP-FRC plate. Through the computer program ABAQUS, a numerical study focusing on the nonlinear analysis of finite elements was carried out. The FEM was verified using the experimental studies simple RC beam with/without openings were cast and tested. The UHP-FRC plates were used on both sides of the RC beam around the opening. The numerical study was carried out to investigate the impacts of using UHPFRC plates with five different thicknesses $(10,20,30,40$ and 50) $\mathrm{mm}$ with constant width $100 \mathrm{~mm}$ and three different plates with width $(50,70$ and100) $\mathrm{mm}$ with constant thickness $20 \mathrm{~mm}$. The result showed that the use of plates thickness from 10 to $20 \mathrm{~mm}$ increased the ultimate loads about $52.99 \%$ to $62.81 \%$, the use of plates thickness from 30up to $50 \mathrm{~mm}$ could not provide any enhancement in the ultimate loads, and the use of plates with different width from 50 up to $100 \mathrm{~mm}$ increased the ultimate loads about $23.91 \%$ to $62.81 \%$. Overall, the strengthening technique using UHP-FRC plate of RC beam with the opening significantly enhance the ultimate load, ductility and shear strength.

KEYWORDS: Numerical, Strength simple Beams, Rectangular opening, UHP-FRC, Finite element modeling, and ABAQUS. 


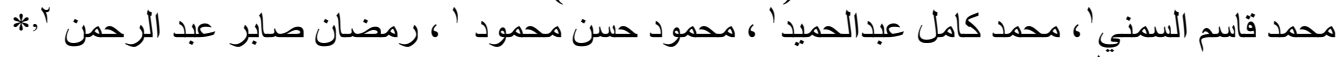

$$
\begin{aligned}
& \text { 'قسم الهندسة المدنية , كلية الهندسة , جامعة الاز هر, القاهرة , مصر 'ر }
\end{aligned}
$$

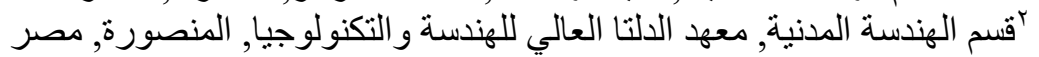

$$
\begin{aligned}
& \text { * البريد الاليكتروني للباحث الرئيسي: و }
\end{aligned}
$$

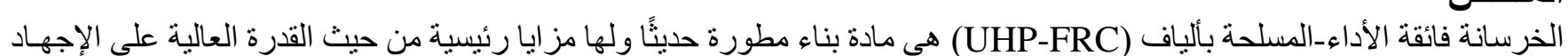

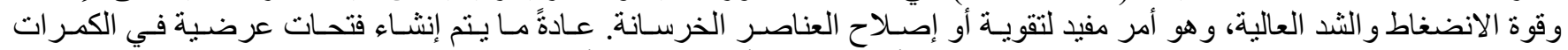

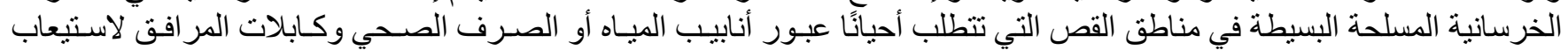

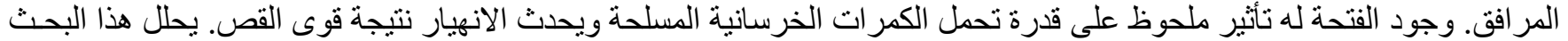



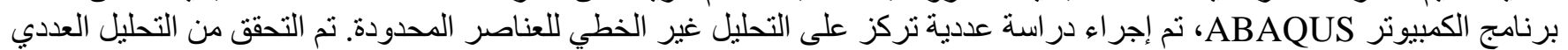

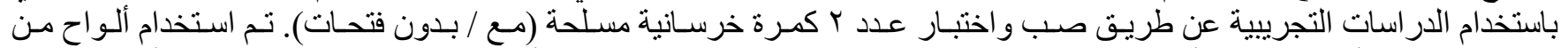

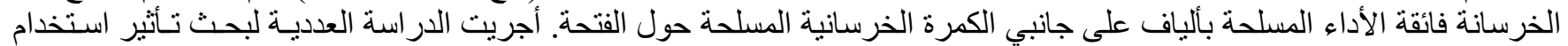

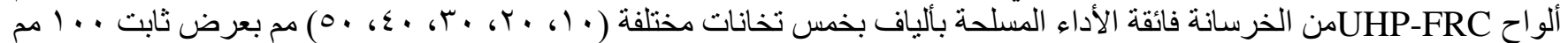

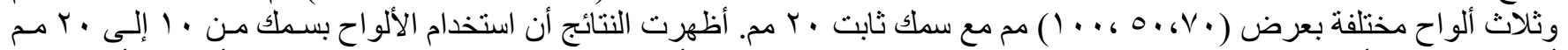






النهائي و اللبونة وقوة القصة التص بشكل كبير.

الكلمات المفتاحية: عدديا، اجهاد الكمرات البسيطة، الفتحات المستطيلة، خرسانة فائقة الأداء مسلحة بألياف، نمذجة العناصر المحدودة، أباكوس

\section{INTRODUCTION}

Some existing old structural buildings may require some adjustments in use, which requires making adjustments in the facility's infrastructure's paths from changing the positions of the paths of electricity, air conditioning, water, and sewage pipes. Accordingly, new ducts will be opening in the existing beams, which causes a change in the behavior and will lose strength and rigidity of beams. In addition, making openings leads to the concentration of stress and early cracking around the opening region due to discontinuities or disruptions in the normal stress flow. Therefore, similar to any discontinuity, special reinforcement should be provided in sufficient quantities to control the width of the crack and to avoid possible premature beam failure [1]. Many systems of (RC) beams must be rehabilitated or strengthened to enhance the properties of structural efficiency and durability. There are many approaches with various goals for strengthening and retrofitting RC systems. Ahmed et al[2]compared the repair effectiveness of $\mathrm{RC}$ beam with opening using variable steel plate thickness and CFRP with a thickness of $1.2 \mathrm{~mm}$. The results showed that the CFRP plate is more effect than steel plates in externally bonded and maximum load capacity. Although, the use of steel plates for strengthening has gained popularity. Some disadvantages have been identified such as corrosion of steel and technique of shear connector need for many creating joint systems [3]. In the last decade, many more researchers have studied the strengthening and retrofitting of RC beams such as using RC jacketing or fiber reinforcement polymers. Both techniques have improved power and energy dissipation capacity. Tahsiri et al[4]indicated that the RC jacketing proved the flexure failure and ductility. while, the FRP method cannot provide sufficient ductility and debonding due to small deflection. The retrofitting technique using FRP laminates can lead to a fragile retrofit structure failure due to mismatching of FRP and concrete tensile strength and stiffness[5]. These disadvantages have given rise to the growth of cement-based retrofitting materials due to their compatibility with concrete. Several ultra-high performance concrete (UHP-FRC) materials 
have been developed. The UHP-FRC improved the load-carrying capacity and enhanced the service life rehabilitation; strengthening has become an acceptable method. Limited research has been conducted into the effectiveness of existing rehabilitation and strengthening methods using externally bonded UHP-FRC. The (UHP-FRC) is a preferred technique used in the strengthening of Structural systems due to its excellent mechanical properties, very high compression and tension strength. UHP-FRC mechanical properties have been thoroughly studied[6-11].Bahraq et al[12]studied the shear behavior of RC beams strengthened by UHP-FRC jacketing. Before strengthening of RC beams prepared surfaces by sand blasting and cast plates in situ with thickness $30 \mathrm{~mm}$. The result showed the enhancement of the shear capacity and ductility. Lampropoulos et al [13] compared the effectiveness of the use of the UHPFRC layer with traditional strengthening using RC layers on RC beams. Three specimens were strengthened with UHP-FRC with plate $50 \mathrm{~mm}$. The first beam strengthened in tension side, the second beam strengthened in compression side and the last specimen strengthened on three sides. The results showed that superior performance was for the one strengthened with three sides UHPFRC jackets. laminates[14] studied the flexural behavior of RC beams strengthened with UHP-FRC performance layer. The specimens were strengthened with $30 \mathrm{~mm}$ UHP-FRC thickness using two different bonding methods: epoxy gluing and mechanical anchoring. To improve the success of the used methods, longitudinal reinforcement bars were also added to the layer. The results show that the use of the UHPFRC layer with anchoring is an efficient method to improve the load-carrying capacity.

In the previous studies, it was shown that strengthening the beam with the use of UHP-FRC material has a significant influence on the behavior of the beams. In this paper, the behavior of strengthened RC beam with opening in shear zone under static load using prefabricated UHP-FRC plates will be studied.

\section{EXPERIMENTAL PROGRAM}

The experimental works consisted of two control RC beams, one of them without opining (B1) and another with opining (B2) were casted and tested under two-point static loads to evaluate the behavior of the RC beam with and without opening in the shear zone. The specimens as shown in Table 2.

Table 1: List of Experimental Test specimen's

\begin{tabular}{|c|c|c|c|c|c|c|}
\hline $\begin{array}{l}\text { Group } \\
\text { Name }\end{array}$ & $\begin{array}{l}\text { Specimen } \\
\text { Code }\end{array}$ & $\begin{array}{l}\text { Dimensions } \\
\text { Length } \mathrm{x} \text { Width } \mathrm{x} \\
\text { depth }(\mathrm{mm})\end{array}$ & $\begin{array}{l}\text { Opening's } \\
\text { dimension }\end{array}$ & $\begin{array}{c}\text { Thickness of } \\
\text { UHP-FRC } \\
\text { plate }(\mathrm{T})\end{array}$ & $\begin{array}{c}\text { Width of } \\
\text { UHP-FRC } \\
\text { Plate }(\mathrm{W})\end{array}$ & $\begin{array}{l}\text { Strengthen } \\
\text { technique }\end{array}$ \\
\hline \multirow{2}{*}{  } & B1 & \multirow{2}{*}{ 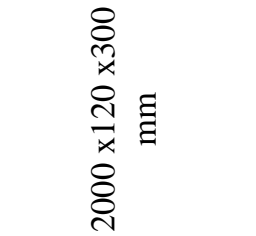 } & No opening & --- & \multirow[b]{2}{*}{---------- } & ---- \\
\hline & B2 & & $\begin{array}{c}100 \times 200 \mathrm{~mm} \\
\text { at } 125 \mathrm{~mm} \text { from } \\
\text { support }\end{array}$ & $\cdots$ & & \\
\hline
\end{tabular}

\section{NUMERICAL PROGRAM}

The numerical works consisted of ten specimens were tested under two-point static loads. The specimens divide into three groups as shown in Table 2. (Group1) consisted of two control RC beams, one of them without opening (B1) and another with opening (B2). (Group2) consisted of five specimens from beam with opening (B2) strengthened with different thicknesses (10, 20, 30, 40 and 50) mm and constant width $100 \mathrm{~mm}$ on both sides of the RC beam around the opening. (Group3) consisted of three specimens from beam with opening (B2) strengthened with constant thicknesses $20 \mathrm{~mm}$ and different widths $(50,70$ and100) $\mathrm{mm}$ on both sides around the opening.

Table 2: List of numerical test specimens and variables strengthening methods 


\begin{tabular}{|c|c|c|c|c|c|c|}
\hline $\begin{array}{l}\text { Group } \\
\text { Name }\end{array}$ & $\begin{array}{l}\text { Specimen } \\
\text { Code }\end{array}$ & $\begin{array}{l}\text { Dimensions } \\
\text { Length } \mathrm{x} \text { Width } \mathrm{x} \\
\text { depth }(\mathrm{mm})\end{array}$ & $\begin{array}{l}\text { Opening's } \\
\text { dimension }\end{array}$ & $\begin{array}{l}\text { Thickness of UHP- } \\
\text { FRC plate (T) }\end{array}$ & $\begin{array}{l}\text { Width of } \\
\text { UHP-FRC } \\
\text { Plate (W) }\end{array}$ & $\begin{array}{l}\text { Strengthen } \\
\text { technique }\end{array}$ \\
\hline$\Xi \tilde{\Xi}$ & B1 & \multirow{10}{*}{ 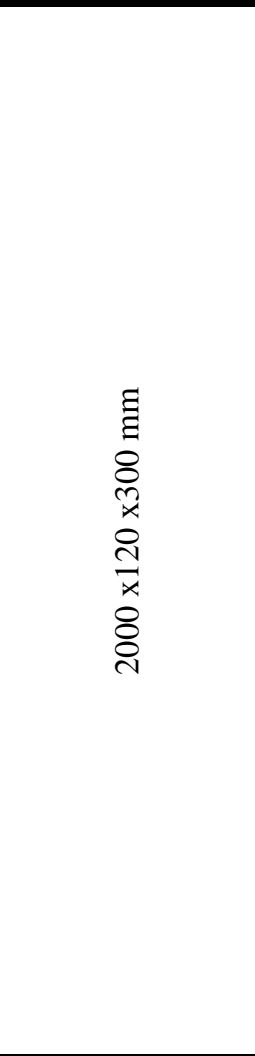 } & No opening & --------- & & --------- \\
\hline 远 & B2 & & \multirow{9}{*}{  } & --------- & & ---------- \\
\hline \multirow{5}{*}{ 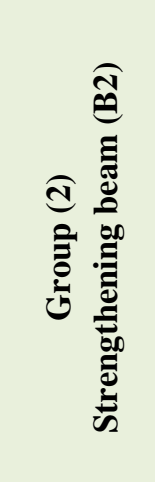 } & B2-T10 & & & $10 \mathrm{~mm}$ & \multirow{5}{*}{$100 \mathrm{~mm}$} & \multirow{5}{*}{$\begin{array}{l}\text { UHP- FRC plate } \\
\text { around the } \\
\text { openings with } \\
\text { variable thickness }\end{array}$} \\
\hline & B2-T20 & & & $20 \mathrm{~mm}$ & & \\
\hline & B2-T30 & & & $30 \mathrm{~mm}$ & & \\
\hline & B2-T40 & & & $40 \mathrm{~mm}$ & & \\
\hline & B2-T50 & & & $50 \mathrm{~mm}$ & & \\
\hline \multirow{3}{*}{  } & B2-W50 & & & \multirow{3}{*}{$20 \mathrm{~mm}$} & $50 \mathrm{~mm}$ & \multirow{3}{*}{$\begin{array}{l}\text { UHP- FRC plate } \\
\text { around the } \\
\text { openings with } \\
\text { variable width. }\end{array}$} \\
\hline & B2-W70 & & & & $70 \mathrm{~mm}$ & \\
\hline & B2-W100 & & & & $100 \mathrm{~mm}$ & \\
\hline
\end{tabular}

\subsection{Materials Properties}

\subsubsection{Concrete}

The mixed design of concrete according to the Egyptian code of practice is shown in Table 3. The concrete mix consisted of Portland cement type CEM I 42.5 R, coarse aggregate, fine aggregate, and clean drinking freshwater, for casting the $\mathrm{RC}$ beams. The cube specimens for the compressive strength test $f_{c u}(150 \times 150 \times 150 \mathrm{~mm})$, the cylinder specimens for compressive strength $\mathrm{f}_{\mathrm{c}}^{\prime}$ and split tensile $f_{c t}$ tests (diameter $=150 \mathrm{~mm}$ and height $=300 \mathrm{~mm}$ ) as shown in Figure 1 .

\subsubsection{UHP-FRC for strengthening the RC Beams}

The UHP-FRC mix design is based on the reference mixtures available in the literature and various laboratory studies[11]. The UHP-RFC mixture consisted of Portland cement type CEM I 52.5 R, silica fume, quartz sand, quartz powder, and water at a ratio of (1: 0.25: 1.1: 0.4: 0.22). The volume fraction of steel fibers was $2 \%$. Corrugated segment steel fibers $(25 \mathrm{~mm}$ in length and $1 \mathrm{~mm}$ in diameter). A Superplasticizer (1.5\% of the dry mass of cement and silica fume) was added for improving the workability of the mix. The mix proportions used as a strengthening material in this study are listed in Table 3. The cube specimens for compressive strength test $f_{c u}(50 \times 50 \times 50 \mathrm{~mm})$, the cylinder specimens for compressive strength $\mathrm{f}_{\mathrm{c}}^{\prime}$ and split tensile $f_{c t}$ (diameter $=50 \mathrm{~mm}$ and height $=100 \mathrm{~mm}$ ) as shown in Figure 1. The samples of concrete and UHP-FRC were curing with standard moisture treatment. The samples are kept in water after demolishing for treatment until the test date, after 28 days. The tests for 
each investigation were carried out using a universal test machine in Delta Higher Institute for Engineering and Technology with a total capacity of $600 \mathrm{KN}$ as shown in Figure 1.The Experimental results for NC and UHP-FRC mix design obtained in Table 4.

Table 3: Mix design of UHP-FRC and NC

\begin{tabular}{|c|c|c|c|c|c|c|c|c|c|c|}
\hline $\begin{array}{c}\text { Materials } \\
(\mathbf{k g} / \mathbf{m 3})\end{array}$ & $\mathbf{C}$ & $\mathbf{S F}$ & $\mathbf{Q S}$ & $\mathbf{Q P}$ & $\mathbf{C A}$ & $\mathbf{F A}$ & $\mathbf{S P}$ & $\mathbf{W}$ & $\mathbf{S F}$ & $\mathbf{w} / \mathbf{c}$ \\
\hline $\mathbf{U H P}-\mathbf{F R C}$ & 788 & 197 & 866.8 & 315 & - & - & 14.77 & 173 & 155 & 0.22 \\
\hline $\mathbf{N C}$ & 350 & - & - & - & 1256 & 628 & - & 150 & - & 0.5 \\
\hline
\end{tabular}

C cement, SF silica fume, QS quartz Sand, QP quartz powder, CA Coarse aggregates, FA Fine aggregates, SP Super plasticizers, W water, SF steel fibers, and W/C Water to cement ratio.

Table 4 Experimental results for NC and UHP-FRC mix design

\begin{tabular}{|c|c|c|c|}
\hline Mixture & $\begin{array}{c}\text { Mean compression } \\
\text { strength } \mathbf{f}_{\mathrm{cu}}(\mathrm{MPa})\end{array}$ & $\begin{array}{c}\text { Mean compression } \\
\text { strength } f_{c}^{\prime}(\mathrm{MPa})\end{array}$ & $\begin{array}{c}\text { Mean Tensile strength, fct } \\
(\mathrm{MPa})\end{array}$ \\
\hline NC & 32.8 & 25 & 2.77 \\
\hline UHP-FRC & 150 & 126 & 12 \\
\hline
\end{tabular}



(a)
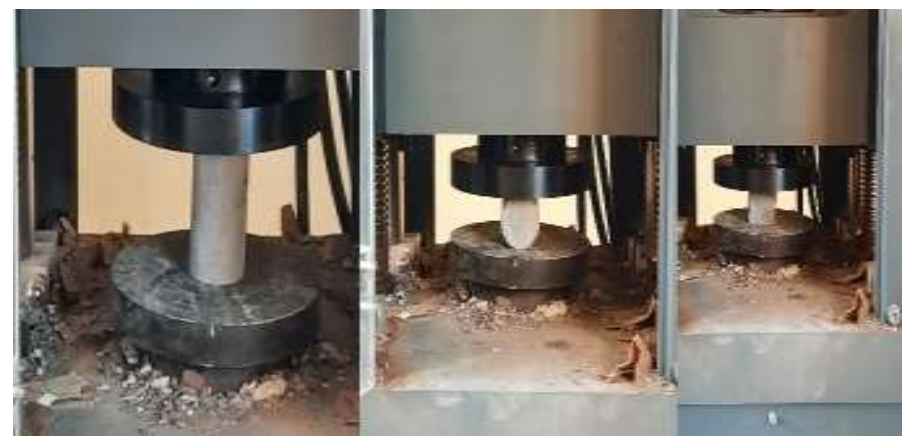

(b)

\subsubsection{Steel reinforcement for the $\mathrm{RC}$ Beams}

Figure 1 Experimental test for (a) NC and (b) UHP-FRC

Results of both the yield and ultimate strengths for 6, 8, and 10mm steel bars are shown in Table 5. The elastic modulus, Es= $209 \mathrm{GPa}$ were the values obtained.

Table 5 Results of yield and ultimate strengths of steel bar reinforcement

\begin{tabular}{|c|c|c|}
\hline Bar diameter $(\mathbf{m m})$ & Yield Strength $\mathbf{( M P a )}$ & Ultimate Strength (MPa) \\
\hline $\mathbf{6}$ & 240 & 350 \\
\hline $\mathbf{8}$ & 360 & 520 \\
\hline $\mathbf{1 0}$ & 525 & 686 \\
\hline
\end{tabular}

\subsection{Specimens Dimension and Reinforcement Detailing}

The dimensions of the RC beam are $120 \mathrm{~mm}$ (wide) x $300 \mathrm{~mm}$ (height) x $2000 \mathrm{~mm}$. The distance between supports was $1800 \mathrm{~mm}$ and the distance between the two applied loads was $600 \mathrm{~mm}$. In addition, the reinforcement details were fixed for all specimens. The tension longitudinal reinforcement was 3D10mm, top reinforcement was 2D8mm and Two branches D 6 mm stirrups @ $150 \mathrm{~mm}$ spacing were used as transverse reinforcement. The geometry and reinforcement details were available for solid beam (B1) as show in Figure 2 and the beam with opening (B2) as show in Figure 3. During the production of the reinforcement cage, the stirrups intercepted the openings at the opening sites; they were cut to simulate the condition of the opening in the existing beam. The test program was performed 
NUMERICAL STUDY ON THE BEHAVIOR OF RC BEAMS WITH OPENINGS STRENGTHENED WITH ULTRA HIGH PERFORMANCE - FIBER REINFORCED CONCRETE (UHP-FRC)

in the testing frame of Reinforced Concrete Laboratory of the Faculty of Engineering, Al- Azhar University as shown in Figure 2.
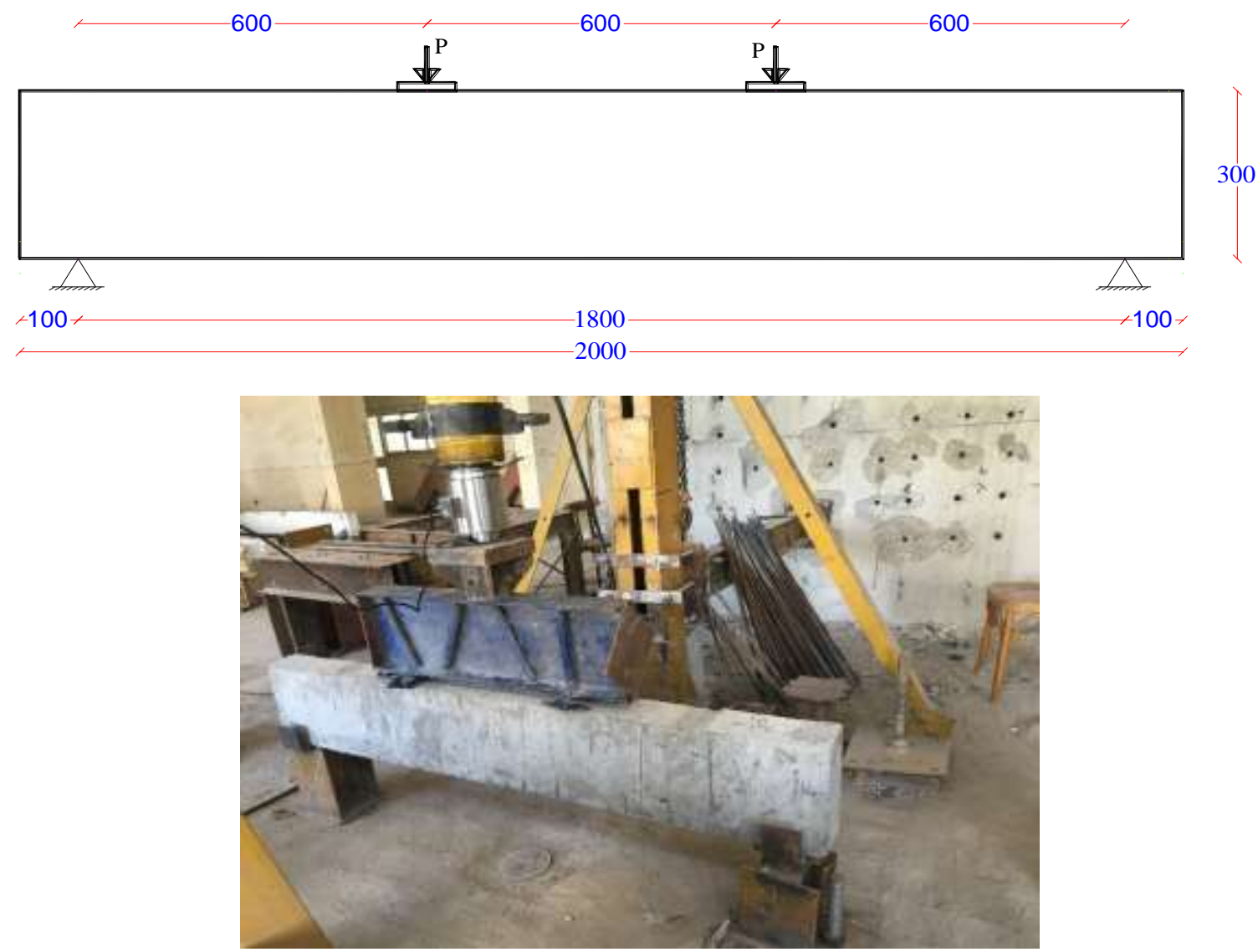

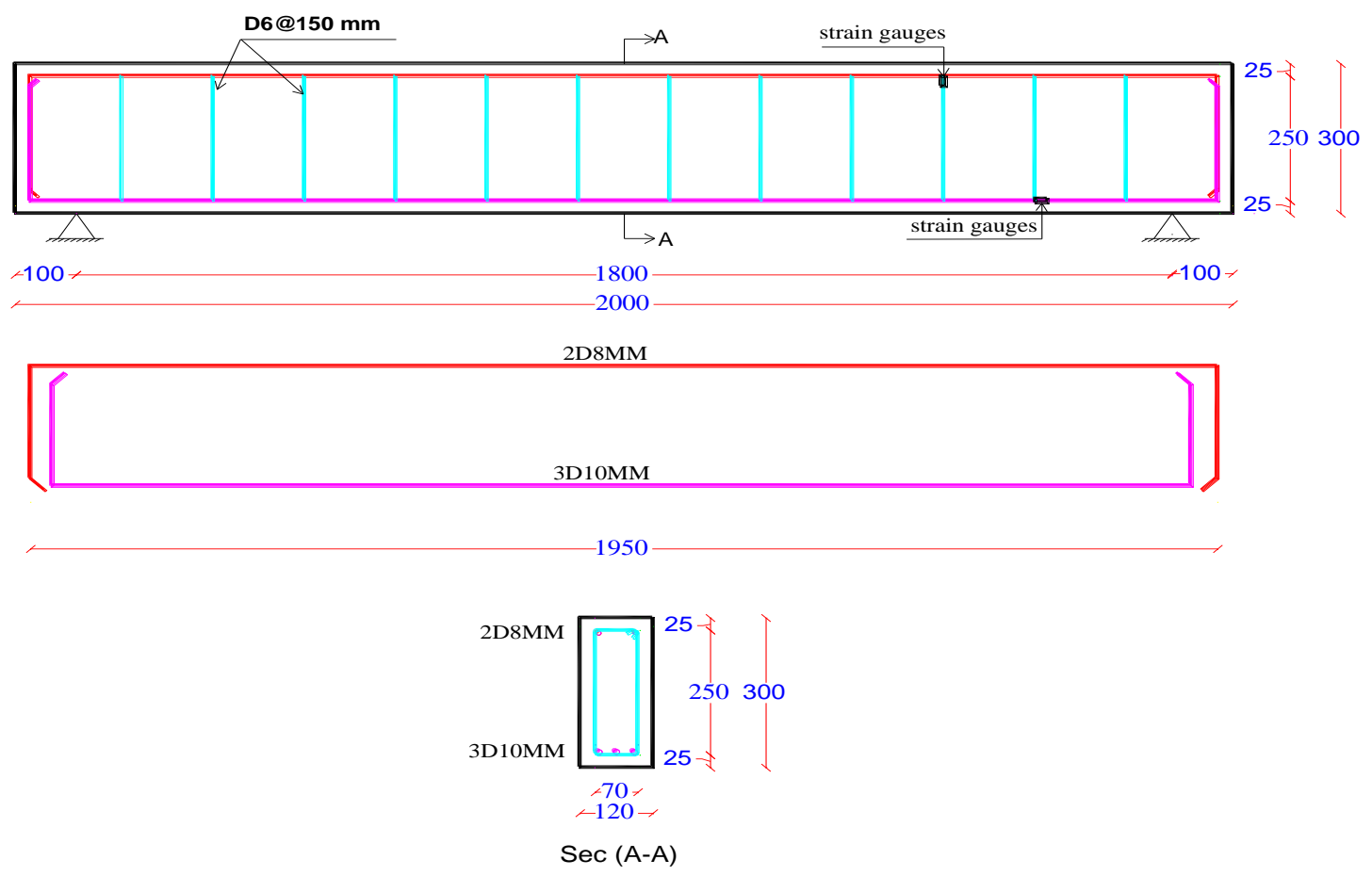

Figure 2 Detailing of control beam B1 without opening a- concrete dimension.

b- Detailing of reinforcement steel.
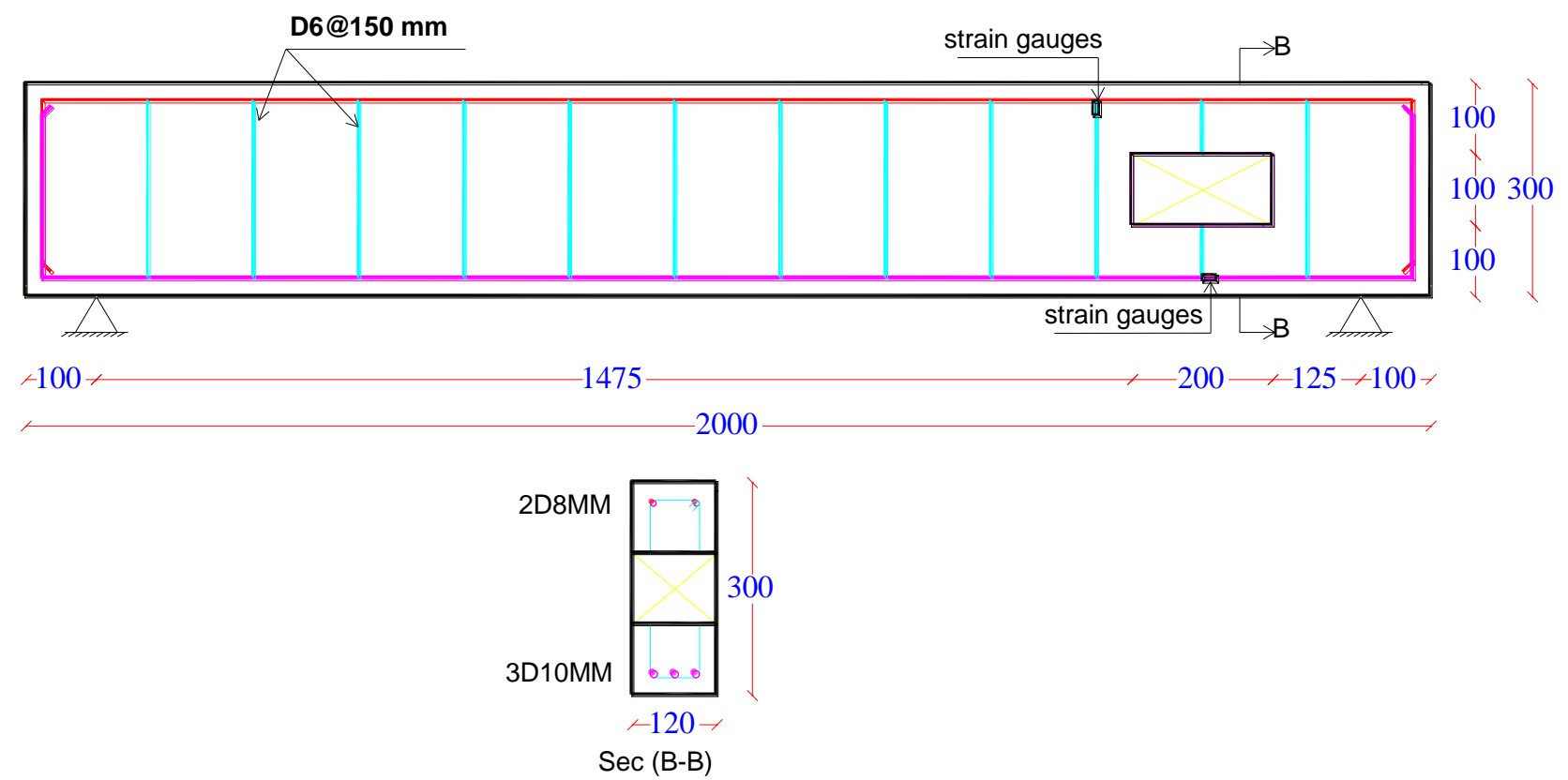

Figure 3 Geometry of the RC beam (B2) with opening and details of reinforcement.

\subsection{Prefabricated UHP-FRC Plates}

The prefabricated UHP-FRC plates for (Group2) with different thicknesses (10, 20, 30, 40 and 50) $\mathrm{mm}$ and constant width $100 \mathrm{~mm}$. The UHP-FRC plates were used on both sides of the RC beam around the opening, as shown in Figure 4. In addition, the prefabricated UHP-FRC plates for (Group3) with 
NUMERICAL STUDY ON THE BEHAVIOR OF RC BEAMS WITH OPENINGS STRENGTHENED WITH ULTRA HIGH

PERFORMANCE - FIBER REINFORCED CONCRETE (UHP-FRC)

constant thicknesses $20 \mathrm{~mm}$ and variable width $(50,70$ and100) $\mathrm{mm}$ on both sides of the RC beam around the opening as shown in Figure 5.
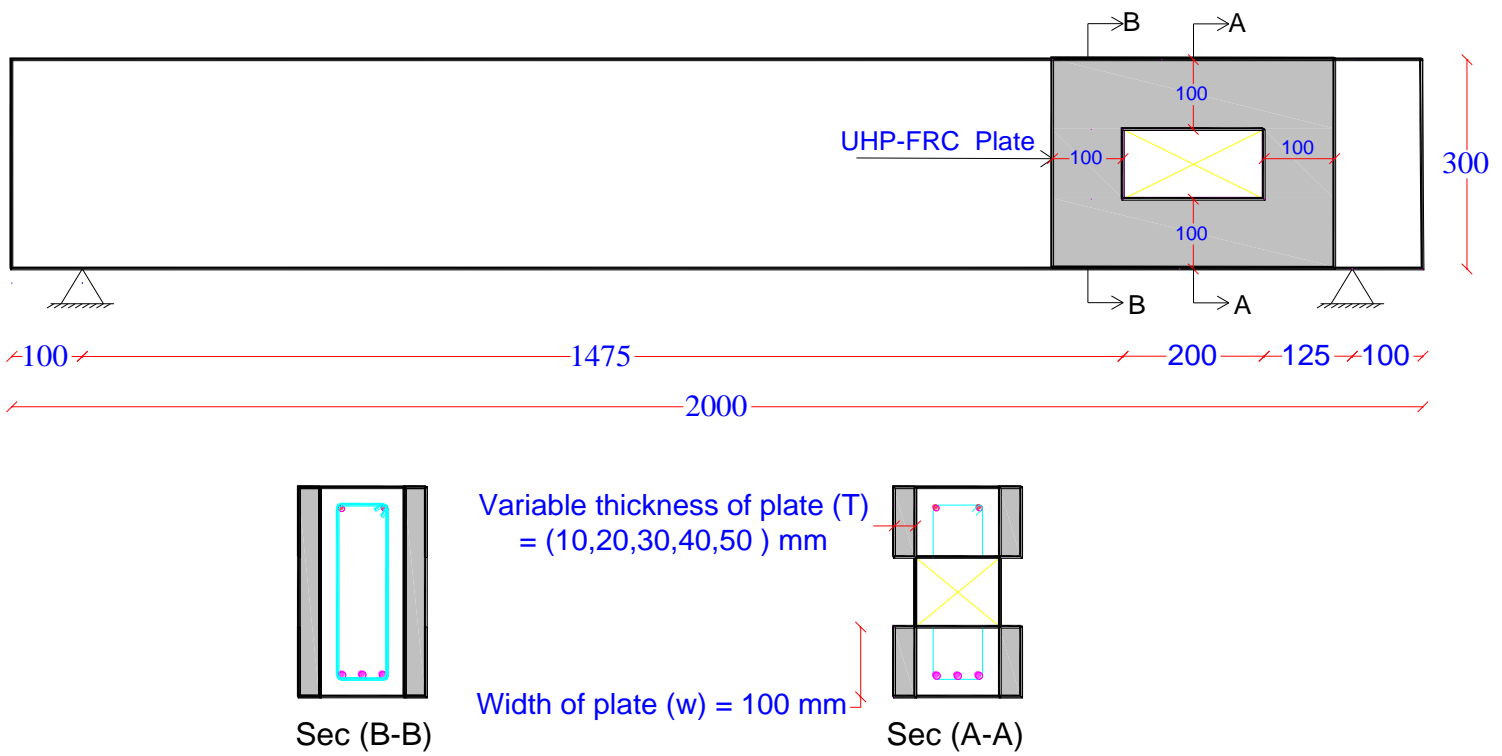

Figure 4 Geometry and details of strengthened beams (B2) with opening for (Group 2) with different thickness UHP-FRC plate specimens.



(a) 


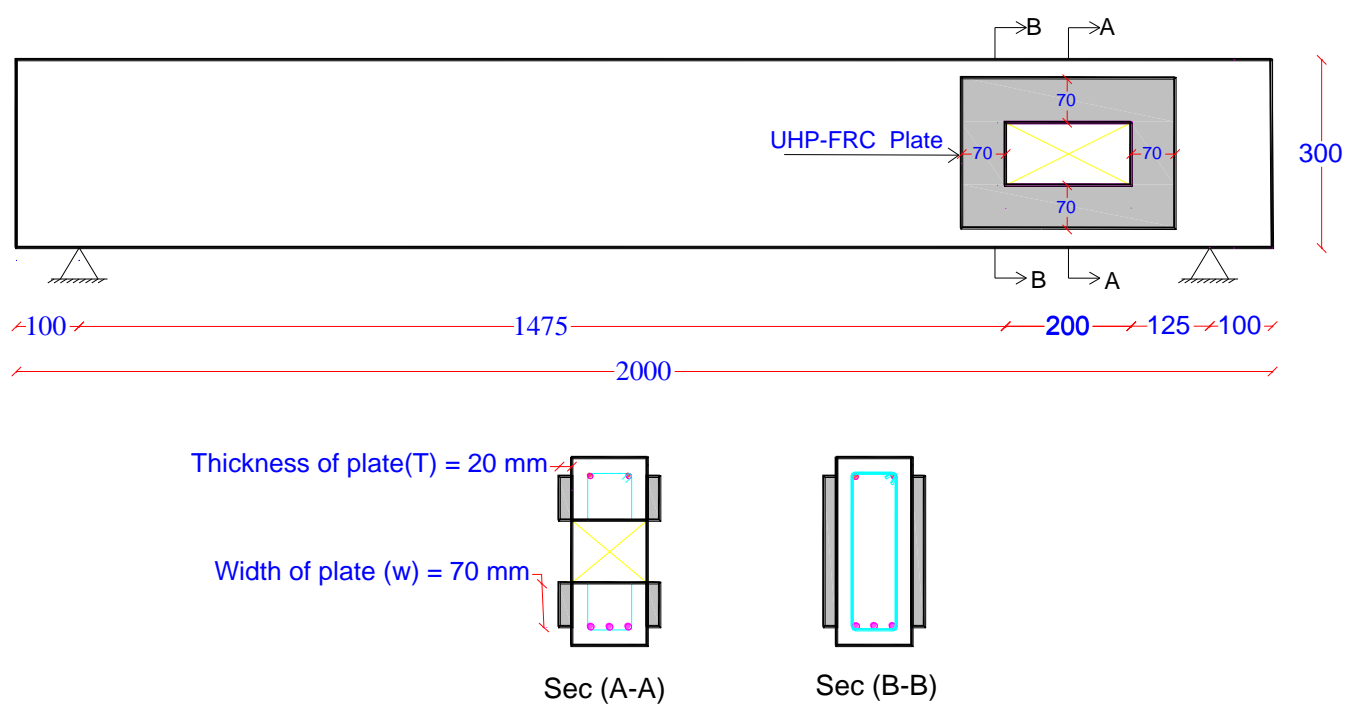

(b)


(c)

Figure 5 Geometry and details of strengthened beams (B2) with opening for (Group 3) with different Width UHP-FRC

\subsubsection{Strain gauges and (LVDTs)} plate specimens.

Tow strain gauges have been mounted on the main reinforcement and stirrups at the opening as shown in Figure 6. The LVDTs were used to measure the displacement at mid span.

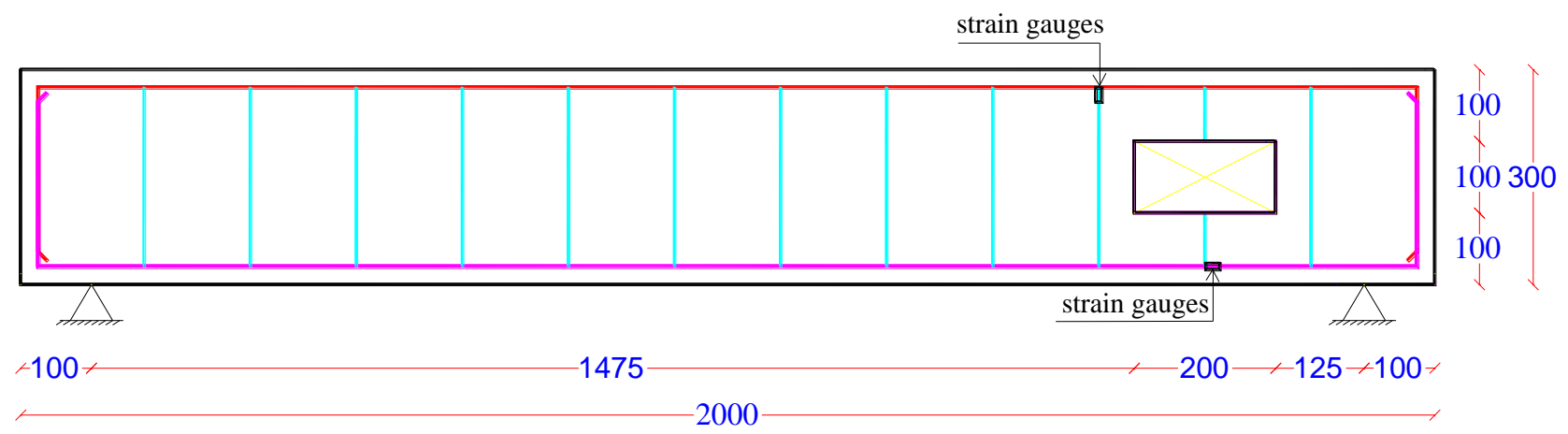

Figure 6 The position of the Strain gauges. 


\section{EXPERIMENTAL RESULTS AND DISCUSSIONS}

\subsection{Crack Patterns}

Control beam (B1):

As the load increased, the first crack started in the mid span of the beam bottom chord, mostly spreading in a vertical direction. The number of cracks increased with an increase in load. Numerous cracks spread from the point of application thus causing the load to fail. Diagonal cracks appeared at a higher load in the shear zones as shown in Figure 7.

Control beam with opining (B2):

As increasing load, the first crack started at the mid span earlier than in the solid beam (B1). Upon further loading, the shear cracks started at edges of the opening and the cracks width increase significantly turning into serious shear cracks, as shown in Figure 8. A summary of the results of the test is provided in Table 6.

Table 6 the results of the solid beam (B1) and beam with opening (B2)

\begin{tabular}{|c|c|c|c|c|c|}
\hline $\begin{array}{c}\text { Group } \\
\text { Name }\end{array}$ & Specimen Code & $\begin{array}{c}\text { Opening's } \\
\text { dimension (mm) }\end{array}$ & $\begin{array}{c}\text { Ultimate Load } \\
(\mathrm{KN})\end{array}$ & $\begin{array}{c}\text { Deflection } \\
\text { (mid span mm) }\end{array}$ & Mode of Failure \\
\hline \\
\hline
\end{tabular}

\subsection{Ultimate Load}

The results as show in Figure 9; the opening in the shear zone greatly reduced beam ultimate load. For non-strengthened openings of height, $100 \mathrm{~mm}$ ( 0.33 of beam height $)$ had the effect of reducing the maximum load to $58.58 \%$ of the solid beam.

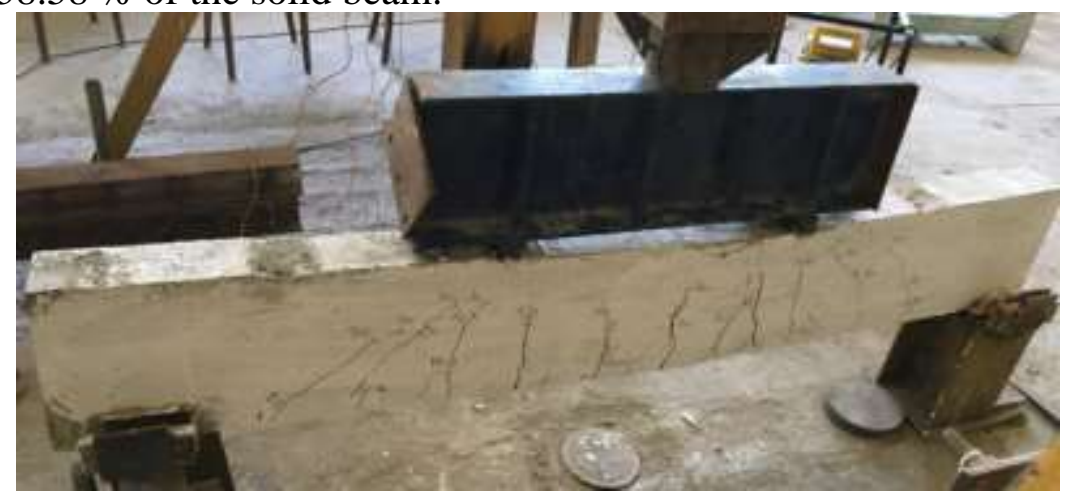

Figure 7 Experimentall crack patterns of control beam (B1) 




Figure 8 Experimental crack patterns of control beam with openings (B2).

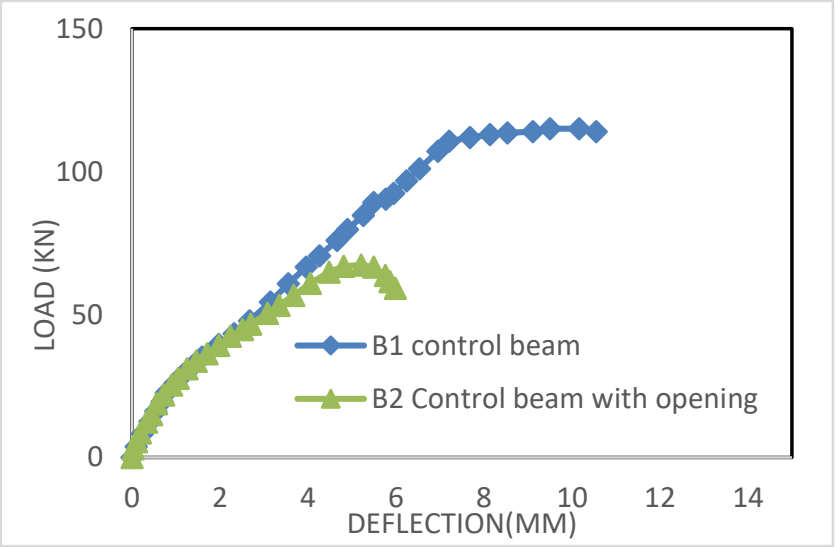

Figure 9 The load-deflection relationship for solid beam (B1) and beam with opening (B2).

\section{NUMERICAL INVESTIGATION}

\subsection{The Material properties of Modeling Concrete}

The 3-D solid continuum element C3D8R is used for the concrete and UHP-FRC models shown in Figure 10a. Steel reinforcement is modeled as individual truss components with steel material properties and cross-sections utilizing the T3D2 element as shown in Figure 10b. The reinforcement is inserted in concrete using a constrain called the Embedded Region which is accessible in ABAQUS. A mesh size of $25 \mathrm{~mm} \times 25 \mathrm{~mm}$ was proposed to divide the simulated RC beams into fine elements. The proposed fine mesh was required to complete accurate results consistent with the experimental response at the level of failure load and failure pattern as shown in Figure 16. Loading and boundary conditions are shown in Figure 17.

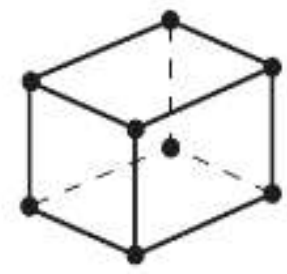

(a) 3D Continuum element (C3D8R)

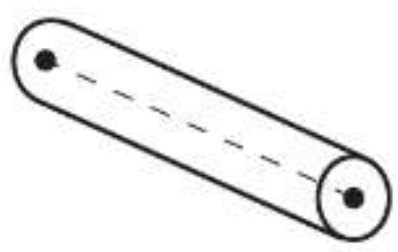

(b) Truss element (T3D2)

Figure 10 Adopted element models for concrete and reinforcement [15] 
The model of concrete damage plasticity was used to simulate both concrete and UHP-FRC. However, there were also two other models of concrete damage plasticity (concrete smeared and brittle cracking) available in ABAQUS. In this study, the model of concrete damage plasticity was applied because it is capable of modeling the complex nonlinear characteristics of concrete and UHP-FRC considering the compression or tension softening behavior. Poisson's ratio for concrete and UHP-FRC was assumed 0.2 and 0.22 respectively

\subsubsection{Concrete}

This model assumes that the two main modes of failure are tensile cracking and compressive crushing [15]. The stress-strain relationship proposed by Saenz [16]was used to create the uni-axial compressive stress-strain curve for concrete is defined in Figure 11a. The fracture energy method was used to specify the post-peak tension failure behavior of concrete. The fracture energy (Gf) is the area under the softening curve is calculated as show in Eq (1), proposed by [17], see Figure 11b. In this equation $G_{f o}$ is a coefficient related to the maximum aggregate size $\left(\mathrm{d}_{\max }=20 \mathrm{~mm}\right)$.

$G_{f}=G_{f o}\left(\frac{f_{c}^{\prime}}{10}\right)^{0.7}$

$G_{f o}=\left(0.0469 d_{\max }^{2}-0.5 d_{\max }+26\right)$ Where $f_{c}^{\prime}$, is given in MPa.

To make a real simulation of the concrete, CDP requires some substantial parameters to be entered into the ABAQUS program. parameters for concrete damage plasticity in NC and UHPFRC materials are listed in

Table 7 according to [18].

Table 7 Concrete damage parameters for concrete and UHP-FRC

\begin{tabular}{|c|c|c|c|c|c|}
\hline Material & $\begin{array}{c}\text { Dilation } \\
\text { angle }\end{array}$ & Eccentricity & $\left(\mathbf{f}_{\mathbf{c o}} / \mathbf{f}_{\text {bo }}\right)$ & $K$ & $\begin{array}{c}\text { Viscosity } \\
\text { parameter }\end{array}$ \\
\hline $\begin{array}{c}\text { concrete and } \\
\text { UHP-FRC }\end{array}$ & 36 & 0.1 & 1.16 & 0.667 & 0 \\
\hline
\end{tabular}

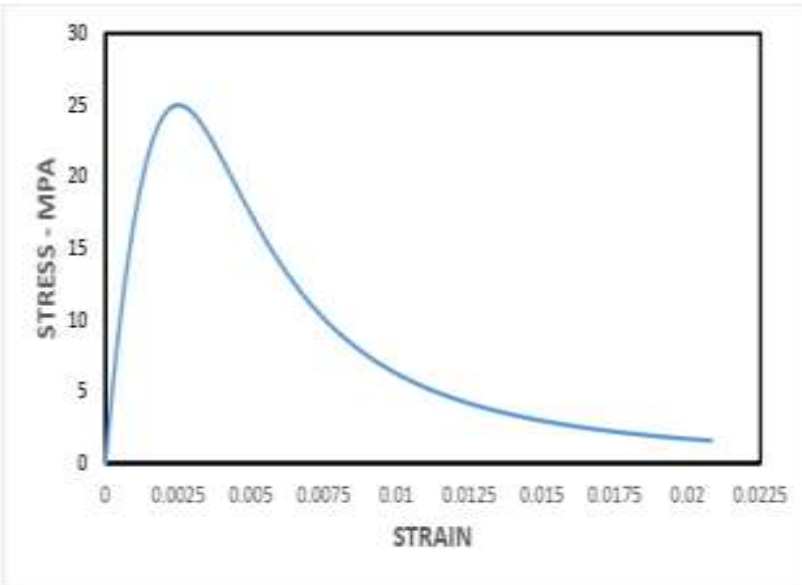

(a)

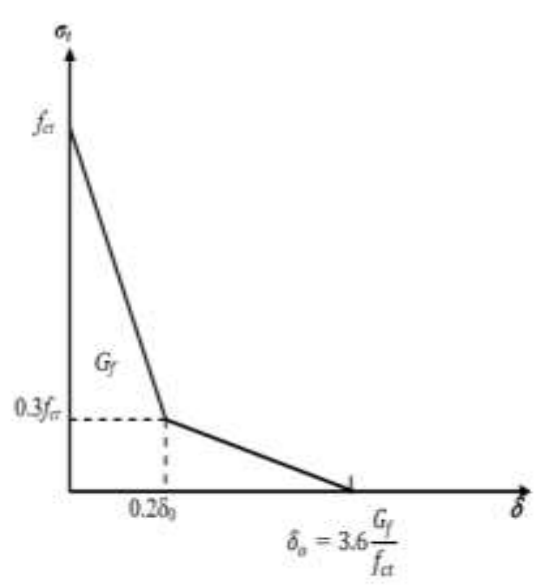

(b)

Figure 11 (a) Stress-strain relationship for concrete under uni-axial compression, (b) tension stiffening model.

\subsubsection{UHP-FRC}

Stress-strain behavior for UHP-FRC under uniaxial compression can be calculated by empirical equations proposed by $\mathrm{Lu}$ et al. [19], as shown in Figure 12a.The damage parameter ( $d_{c}$ proposed by Birtel et al. [20]. The stress-strain response of UHP-FRC under direct tension usually consists of three 
phases: linear elastic, strain hardening, and strain softening phase. Once the matrix begins to crack, the fibres resists the opening of micro-cracks by fibre bridging and UHP-FRC keeps going until the fibres start to pull out from the matrix. The gain in strength is nonlinear in the strain hardening zone whereas the fiber pulling out leads to the softening phase. as shown in Figure 12b. The damage parameter in tension is assumed to activate once the peak tensile strength is achieved. For the present study, the damage parameter is recommended by Mahmud et al. [21].

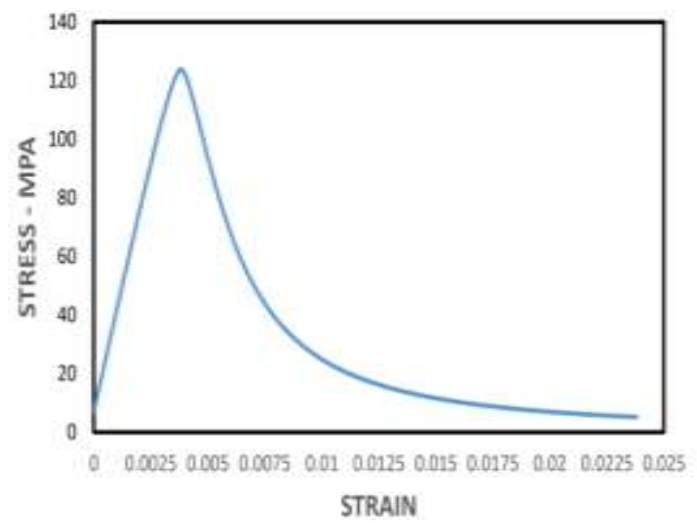

(a)



(b)

Figure 12 (a) Stress-strain relationship for UHP-FRC under uni-axial compression, (b) Uniaxial stress- strain curve for UHPFRC [22].

\subsubsection{Steel reinforcement}

Steel, as illustrated in Figure 13. For tension and compression, it is assumed that the steel reinforcement is an elastic-perfectly plastic material. The experimental result is shown in Table 5. Poisson's ratio was assumed 0.3 for steel.



Figure 13 Stress - strain behaviour of steel.

\subsubsection{Interface contact modeling between concrete and UHP-FRC}

Bond is a critical parameter in strengthening systems as it provides the shear transfer between concreteto-concrete surfaces for composite action. Two different models were used to represent the interface between concrete and UHP-FRC. In the first model the interface was modelled as a perfect bond[29] while in the second it was modelled using a cohesive zone model is defined as[25]. In order to simulate cohesive behaviour, it is necessary to define three parts of the behaviour. The first is the part of linear elastic traction-separation zone, the second is the point of initiation of damage, and finally, is the damage evolution zone. as described in Figure 14 demonstrates a graphical interpretation of a simple law on bilinear traction-separation. 


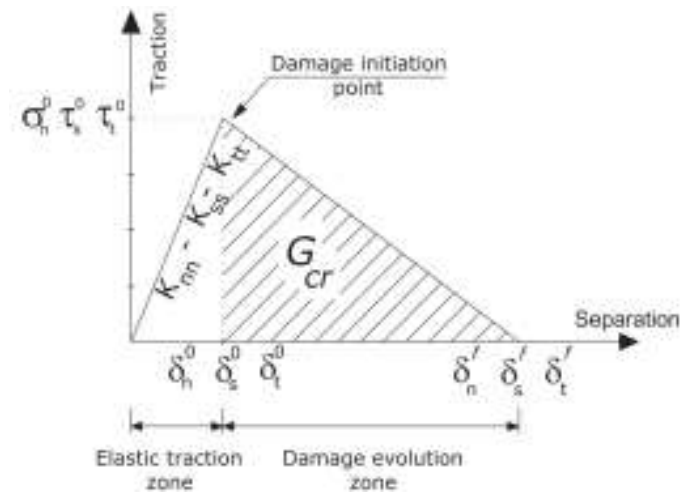

Figure 14 Description of the traction-separation behavior.

There are equations to determine the interface shear strength proposed by previous researchers if this experimental data is not available ${ }^{[25-28]}$. This is usually based on the static friction condition. The first part is the initial stiffness $K_{s s}, K_{t t}$, for the shear directions and $K_{n n}$ for the normal directions. defined in Eq. 2. Where $t_{i}$ is the thickness of the adhesive in $\mathrm{mm}, t_{c}$ is the Thickness of the concrete cover in $\mathrm{mm}$, $E_{i}$ and $E_{c}$ are the elasticity modulus of an adhesive and concrete respectively, and $G_{i}$ is the shear modulus of the adhesive layer $=\frac{E_{i}}{2\left(1+\vartheta_{i}\right)}, G_{c}$ is the shear modulus of the concrete $=\frac{E_{c}}{2\left(1+\vartheta_{c}\right)}, \vartheta_{c}$ and $\vartheta_{i}$ are the Poisson's ratio of concrete and the adhesive layer of 0.2 and 0.3 , respectively.

$K_{s s}=K_{t t}=\frac{1}{\frac{t_{i}}{G_{i}}+\frac{t_{c}}{G_{c}}}, \quad K_{n n}=\frac{1}{\frac{t_{i}}{E i}+\frac{t_{c}}{E_{c}}}$

The second part was required $\sigma_{n}$ is the tensile stress , $\tau_{s}$ and $\tau_{t}$ are shear stresses of the interface, and n, $\mathrm{s}$, and $\mathrm{t}$ refer to the direction of the stress component, see Figure 15. The values used for this study were $\sigma_{n}^{0}=$ maximum tensile strength of the cohesive surface $f_{t}=2.77 \mathrm{MPa}$, and $\tau_{t}^{0}=\tau_{s}^{0}=$ are the maximum shear strength of the cohesive surface, to determine the cohesive surface's maximum shear strength Eq. (3).

$\tau_{\max }=1.5 \beta_{w} f_{t}$

Where $\quad \beta_{w}=\sqrt{\frac{\left(2.25-\frac{b_{f}}{b_{c}}\right)}{\left(1.25+\frac{b_{f}}{b_{c}}\right.}}$

and $b_{f}$ is UHS-FRC plate width, $b_{c}$ is beam width and $f_{t}$ is concrete tensile strength.

The description of this model is available in the ABAQUS material library[30]. The dependence of the fracture energy on the mode mix was defined based on the Benzaggah-Kenane fracture criterion [27]. The values used in this study were $G_{n}^{c}=90 \mathrm{~J} / \mathrm{m} 2, G_{s}^{c}=G_{t}^{c}=900 \mathrm{~J} / \mathrm{m} 2$, and $\eta=1.45$.



Figure 15 8-node 3-D cohesive element. 
NUMERICAL STUDY ON THE BEHAVIOR OF RC BEAMS WITH OPENINGS STRENGTHENED WITH ULTRA HIGH PERFORMANCE - FIBER REINFORCED CONCRETE (UHP-FRC)

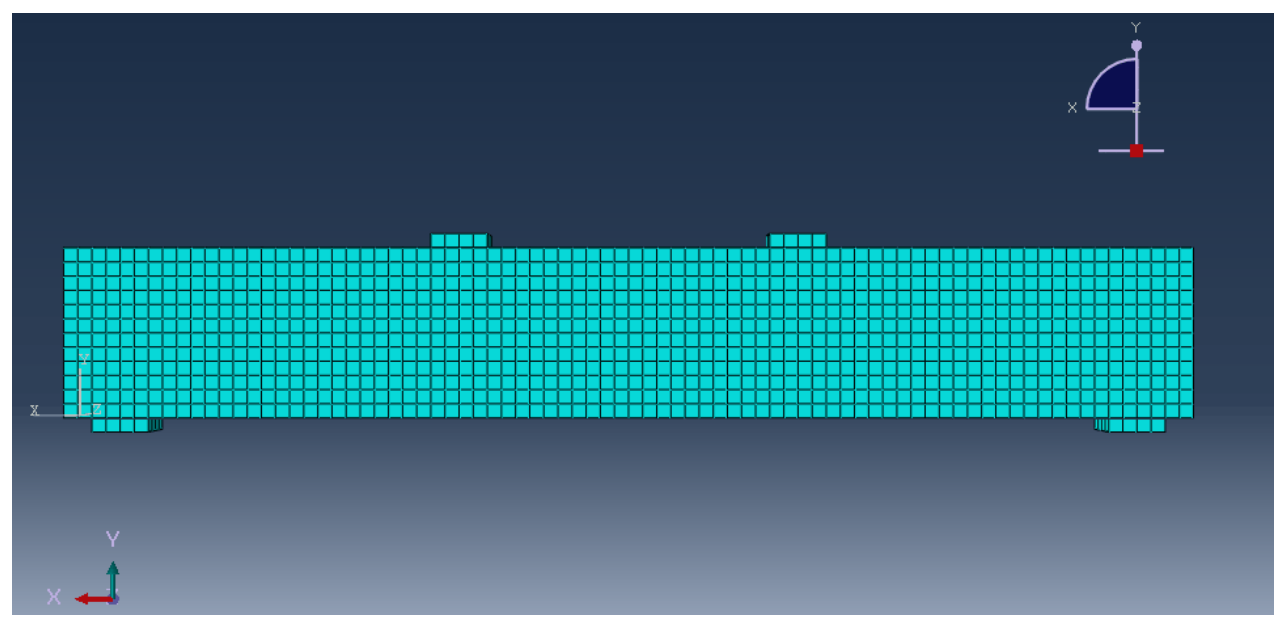

(a) Control beam B1

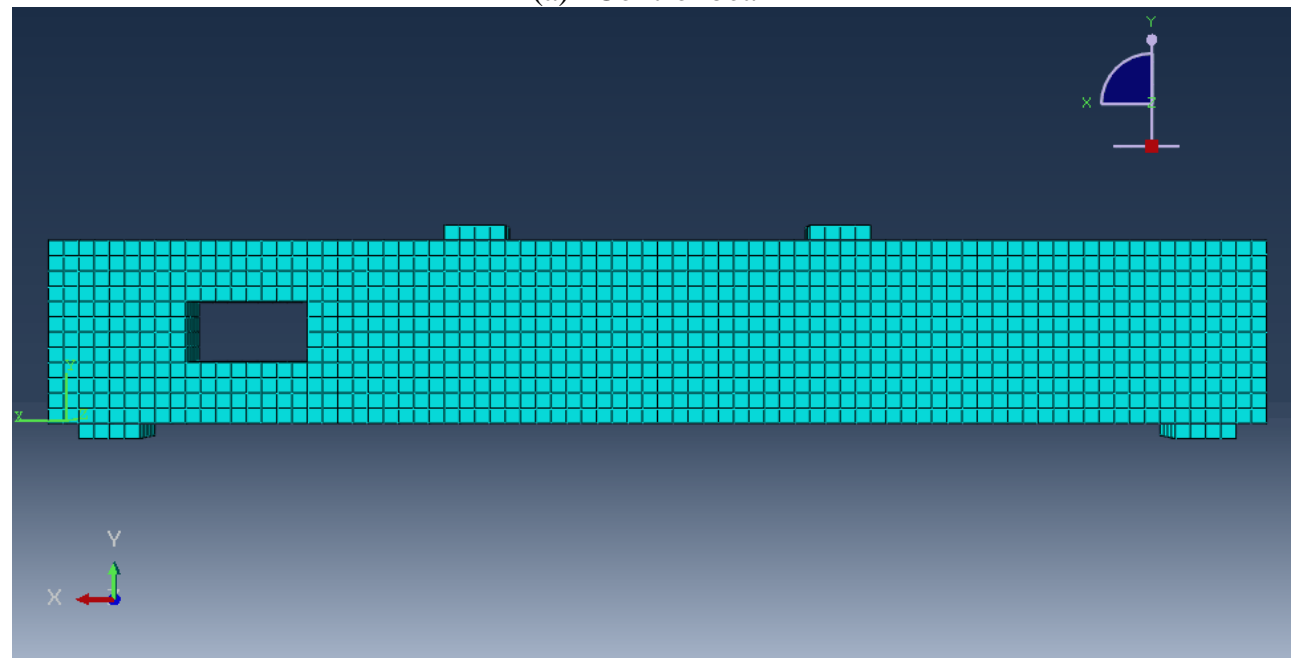

(b) Control beam with opening B2

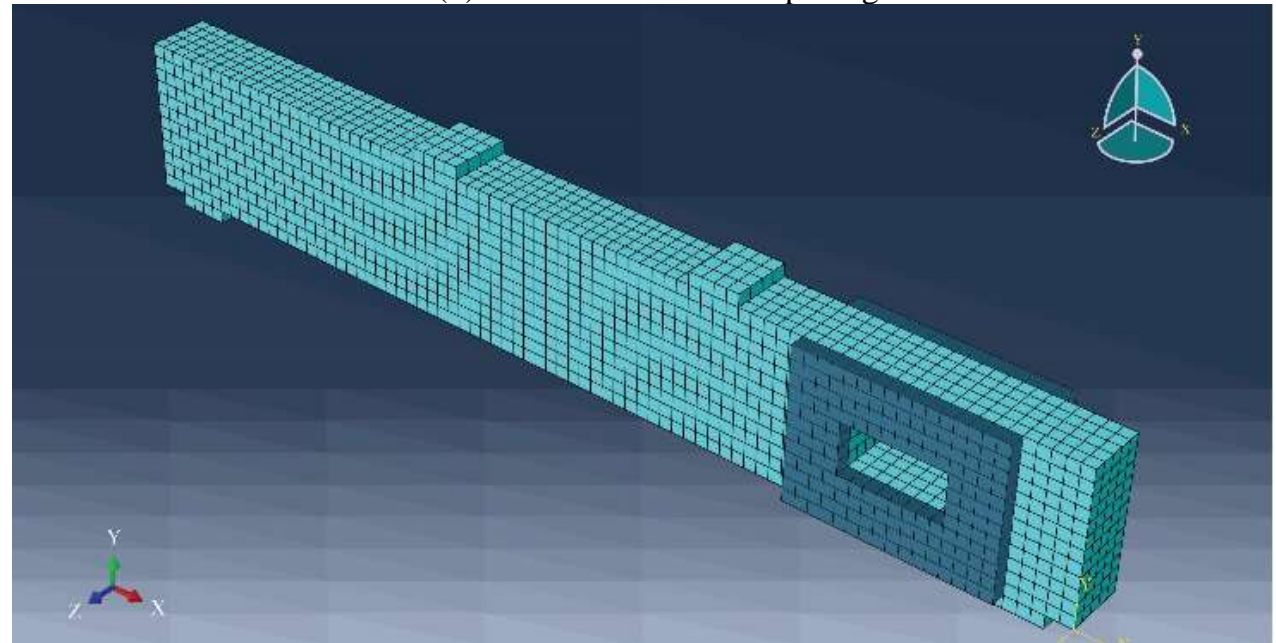

(c) Strengthening beam with opening B2 


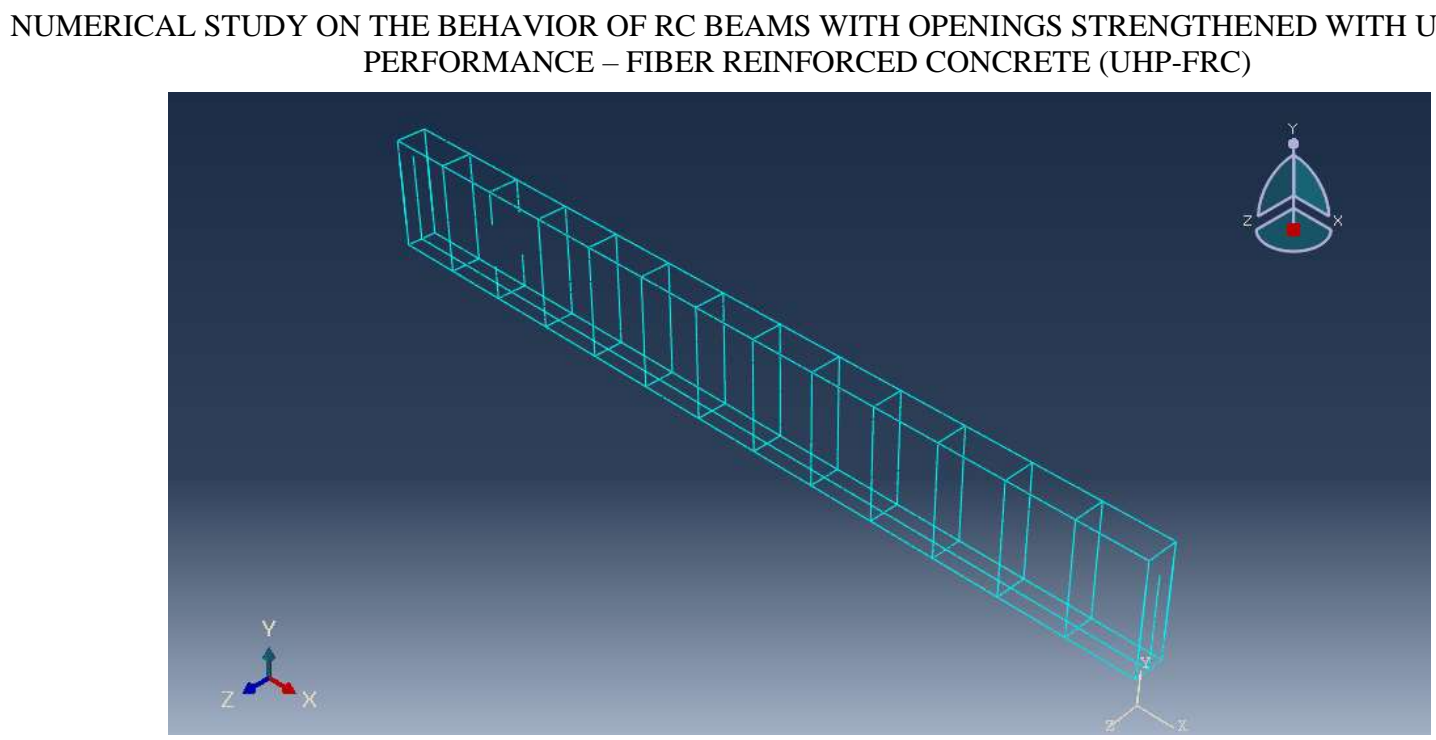

(d) Steel RFT

Figure 16 Geometry of the model meshed element in BAQUS



Figure 17 Loading and boundary conditions in ABAQUS.

\section{EXPERIMENTAL AND FINITE ELEMENT MODEL RESULTS AND DISCUSSIONS Group (1) Control beams}

The results of the proposed FEM were compared with the experimental results to verify its accuracy. The simulation numerical methods are in good agreement with the test results as shown in Figure 18 and Figure 19. Including the relationship between the ultimate load $\mathrm{P}_{\mathrm{u}}$ and the mid-span deflection of the tested beams and the failure modes suggest that the numerical procedure could effectively estimate the behavior of the reinforced concrete beam. The comparison of the maximum failure load and deflection in mid span is obtained in Table 8.

Table 8 shows the comparison between experimental (EXP) and finite element analysis (FEM).

\begin{tabular}{|c|c|c|c|c|c|c|c|c|}
\hline \multirow[b]{2}{*}{$\begin{array}{l}\text { Group } \\
\text { Name }\end{array}$} & \multirow[b]{2}{*}{$\begin{array}{c}\text { Specimen } \\
\text { Code }\end{array}$} & \multirow[b]{2}{*}{$\begin{array}{c}\text { Opening's } \\
\text { dimension } \\
\quad(\mathrm{mm})\end{array}$} & \multicolumn{2}{|c|}{ Experimental } & \multicolumn{2}{|c|}{ Numerical } & \multirow[b]{2}{*}{ Mode of Failure } & \multirow[b]{2}{*}{$\begin{array}{c}\mathrm{P}(\mathrm{FEM}) / \\
\mathrm{P}(\mathrm{EXP})\end{array}$} \\
\hline & & & $\begin{array}{c}\text { Ultimate } \\
\text { Load } \\
(\mathrm{KN})\end{array}$ & $\begin{array}{c}\text { Deflection } \\
\text { (mid span } \\
\text { mm) }\end{array}$ & $\begin{array}{c}\text { Ultimate } \\
\text { Load } \\
(\mathrm{KN})\end{array}$ & $\begin{array}{c}\text { Deflection } \\
\text { (mid span mm) }\end{array}$ & & \\
\hline \multirow{2}{*}{  } & B1 & No opening & 115 & 9.494 & 111.92 & 9.87 & Flexural Failure & 0.97 \\
\hline & $\mathrm{B} 2$ & $100 \times 200 \mathrm{~mm}$ & 67.37 & 5.21 & 64.42 & 4.97 & Shear at opening & 0.956 \\
\hline
\end{tabular}




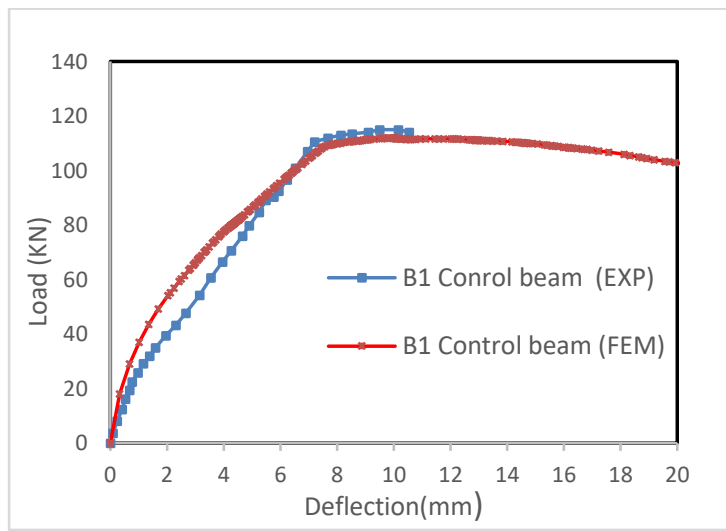

Figure 18 shows the comparison between the experimental and FEM results of the load-deflection relationship for the control beam B1.

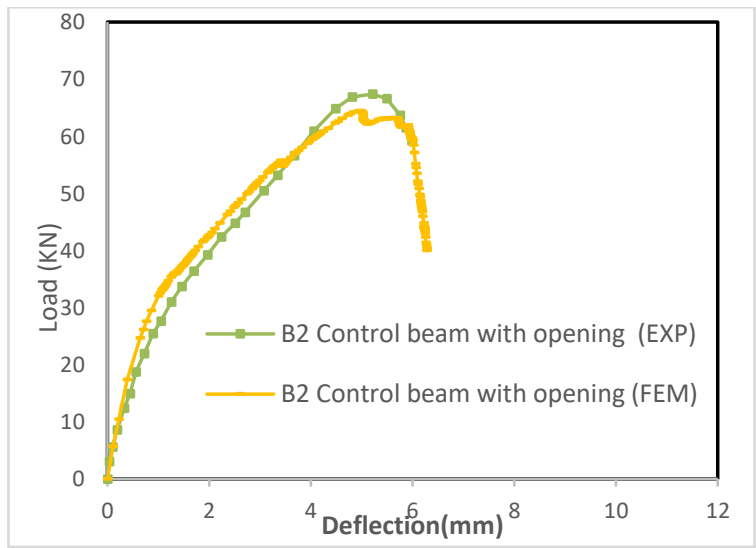

Figure 19 shows the comparison between the experimental and FEM results of the load-deflection relationship for the control beam B2 with opening.

\section{PARAMETRIC ANALYSIS AND ANALYTICAL RESULTS}

The finite element models performed with numerical analysis using ABAQUS predict strictly the analysis and discussion; the effectiveness of strengthened RC beams with the opening at shear zone using UHP-FRC plates.

\subsection{Strengthening RC beam with variable UHP-FRC plates.}

\section{Group (2)}

Strengthened RC beam with opening (B2) using prefabricated UHP-FRC plates with five variable thickness (10, 20, 30, 40 and 50) $\mathrm{mm}$ as shown in Table 9. The plates are located around the opening on two sides with a constant width of $100 \mathrm{~mm}$. The results show that the UHP-FRC plates with a thickness of $10 \mathrm{~mm}$ increase in the ultimate loads about $52.99 \%$ and enhance the deflection at mid-span about $28.19 \%$. Also, the UHP-FRC plates with thickness $20 \mathrm{~mm}$ increase the ultimate loads about $62.81 \%$ and enhance the deflection at mid-span about $45.46 \%$. While the UHP-FRC plates with a thickness of 30, 40 and $50 \mathrm{~mm}$ could not provide any enhancement in the ultimate loads and deflections, as shown in Figure 20.

Table 9 UHPFRC plates used to strengthen RC beam with open (B2) using different thickness.

\begin{tabular}{|c|c|c|c|c|c|c|c|}
\hline $\begin{array}{l}\text { Group } \\
\text { Name }\end{array}$ & $\begin{array}{c}\text { Specimen } \\
\text { Code }\end{array}$ & $\begin{array}{c}\text { Opening's } \\
\text { dimension }\end{array}$ & $\begin{array}{c}\text { Thickness of } \\
\text { UHP-FRC } \\
\text { plate (T) }\end{array}$ & $\begin{array}{c}\text { Width of } \\
\text { UHP-FRC } \\
\text { Plate (W) }\end{array}$ & Ultimate Load & Deflection & Mode of Failure \\
\hline
\end{tabular}


NUMERICAL STUDY ON THE BEHAVIOR OF RC BEAMS WITH OPENINGS STRENGTHENED WITH ULTRA HIGH PERFORMANCE - FIBER REINFORCED CONCRETE (UHP-FRC)

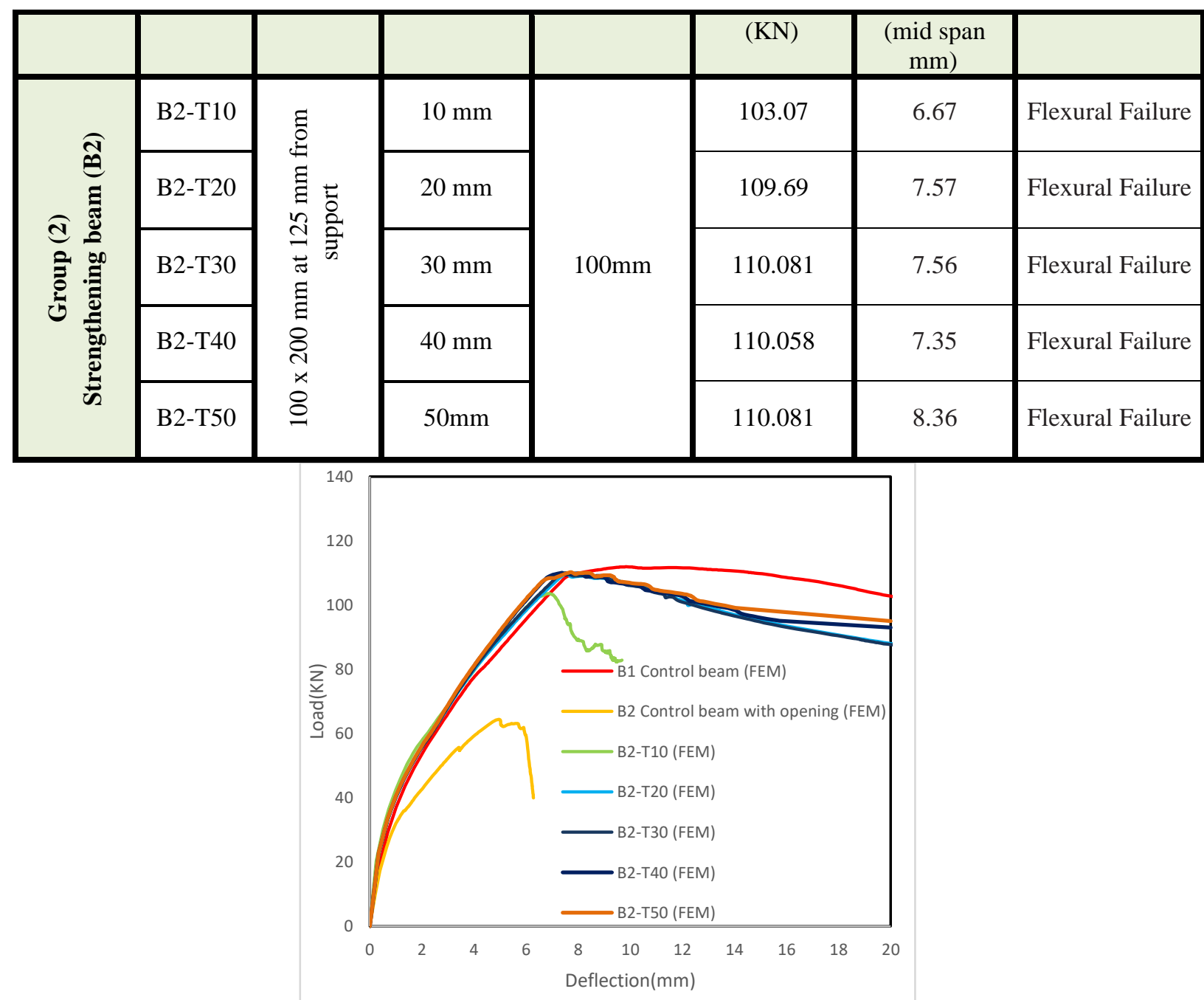

Figure 20 the load-deflection relationship for the beam B2 with opening strengthening using different thickness from UHPFRC plate.

\section{Group (3)}

Strengthened RC beam with opening (B2) using prefabricated UHP-FRC plates with three different widths (50, 70 and 100) $\mathrm{mm}$ as shown in Table 10. The plates are located around the opening on two sides with a constant thickness of $20 \mathrm{~mm}$. The results show that the UHP-FRC plates with a width of 50 $\mathrm{mm}$ increase the ultimate loads about $23.91 \%$. Also, the UHP-FRC plates with width $70 \mathrm{~mm}$ increase in the ultimate loads about $51.88 \%$ and the UHP-FRC plates with width $100 \mathrm{~mm}$ increase the ultimate loads about 62.81\%, as shown in Table 10, and Figure 21.

Table 10 UHPFRC plates used to strengthen RC beam with open (B2) using different width plate.

\begin{tabular}{|c|c|c|c|c|c|c|c|c|}
\hline \multirow{2}{*}{$\begin{array}{l}\text { Group } \\
\text { Name }\end{array}$} & \multirow{2}{*}{$\begin{array}{l}\text { Specimen } \\
\text { Code }\end{array}$} & \multirow{2}{*}{$\begin{array}{l}\text { Opening's } \\
\text { dimension }\end{array}$} & \multirow{2}{*}{$\begin{array}{c}\text { Thickness of } \\
\text { UHP-FRC } \\
\text { plate }(\mathrm{T})\end{array}$} & \multirow{2}{*}{$\begin{array}{l}\text { Width of } \\
\text { UHP-FRC } \\
\text { Plate (W) }\end{array}$} & \multicolumn{4}{|c|}{ Numerical Analysis } \\
\hline & & & & & $\begin{array}{c}\text { Ultimate } \\
\text { Load } \\
(\mathrm{KN})\end{array}$ & $\begin{array}{c}\text { Deflection } \\
\text { (mid span mm) }\end{array}$ & $\begin{array}{c}\text { Increase }(\%) \text { of } \\
\text { ultimate load }\end{array}$ & Mode of Failure \\
\hline 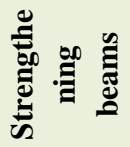 & B2-W50 & & $20 \mathrm{~mm}$ & $50 \mathrm{~mm}$ & 83.48 & 10.41 & 23.91 & Shear at opening \\
\hline
\end{tabular}




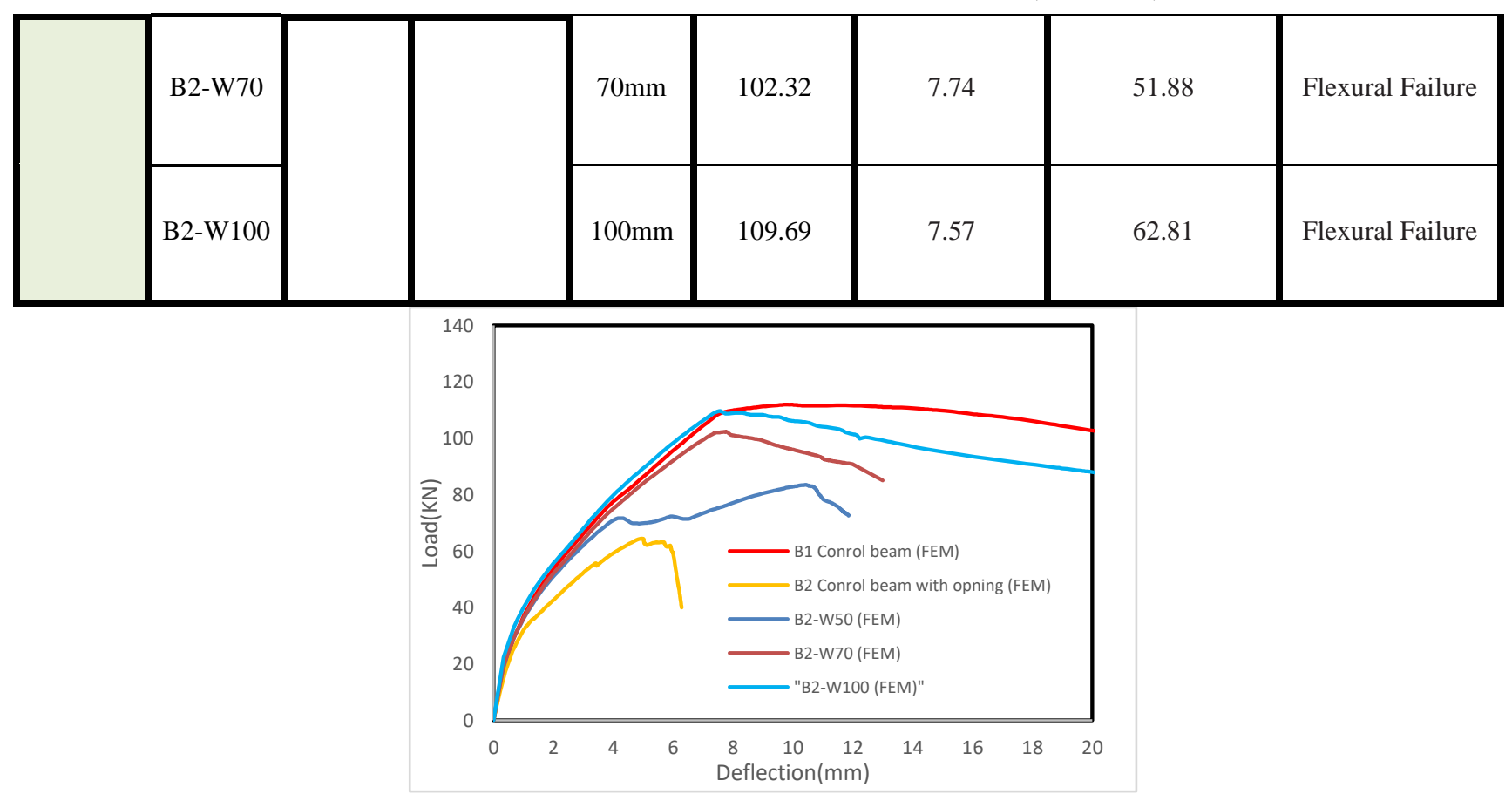

Figure 21 the load-deflection relationship for the beam B2 with opening strengthening using different width from UHP-FRC plate.

\section{FAILURE MODES:}

\section{Control beams (Group1)}

For the specimen control beam (B1), the failure occurred due to flexure failure in the middle of the beam span as shown in Figure 22. These figures show that the cracks started at the middle of the beam for both experimental and finite element model.

For the specimen control beam with opening (B2), the failure occurred due to shear failure under the opening as shown in Figure 23. It was found that the diagonal cracks started from the top of the opening to the nearest point load and started from the bottom of the opening to the nearest support. However, the failure has occurred at the corner of the opening.

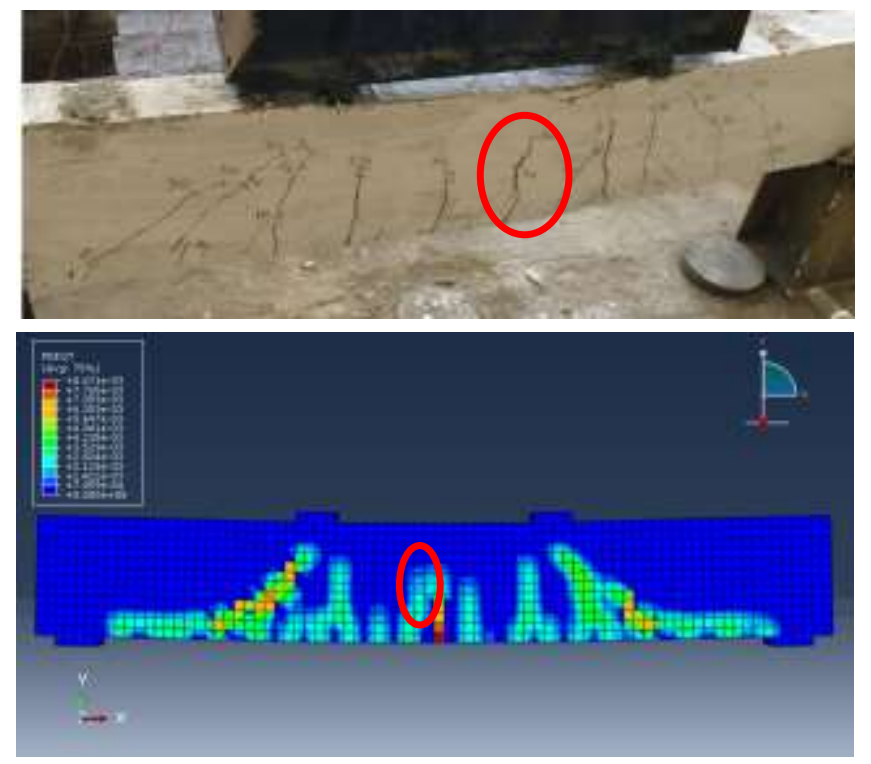

Figure 22 Failure mode for control beam (B1) EXP and FEM. 

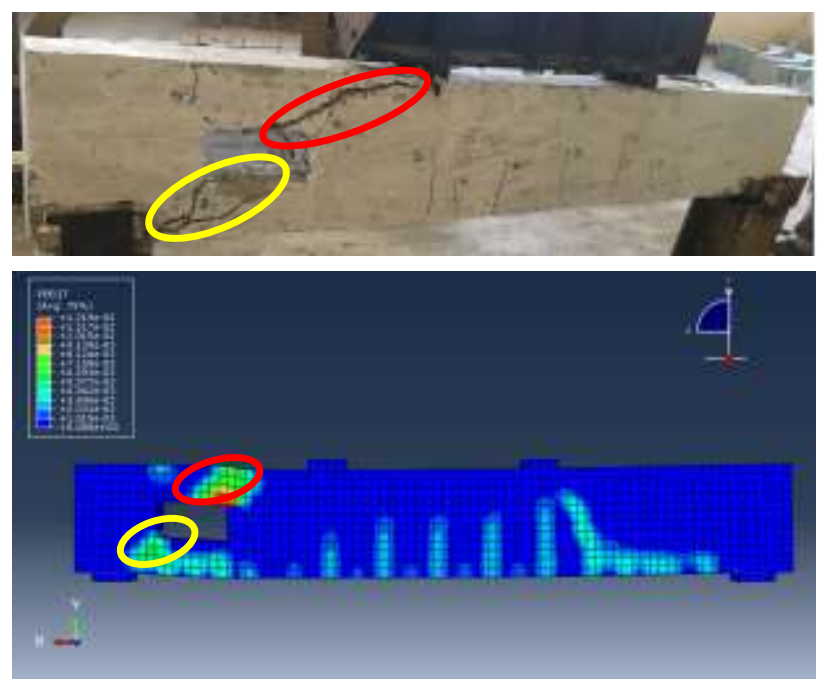

Figure 23 Failure mode for control beam (B2) EXP and FEM.

\section{Strengthened beam B2 (Group 2)}

The beam (B2) with opening strengthened by UHP-FRC plates with different thicknesses $(10,20,30,40$ and 50) $\mathrm{mm}$ and constant width $100 \mathrm{~mm}$ on both sides of the RC beam around the opening. The failure occurred due to the flexure failure of the beam span, as shown in Figure 24. The use of UHP-FRC plate changing the failure mode from shear failure at opening to flexural failure.

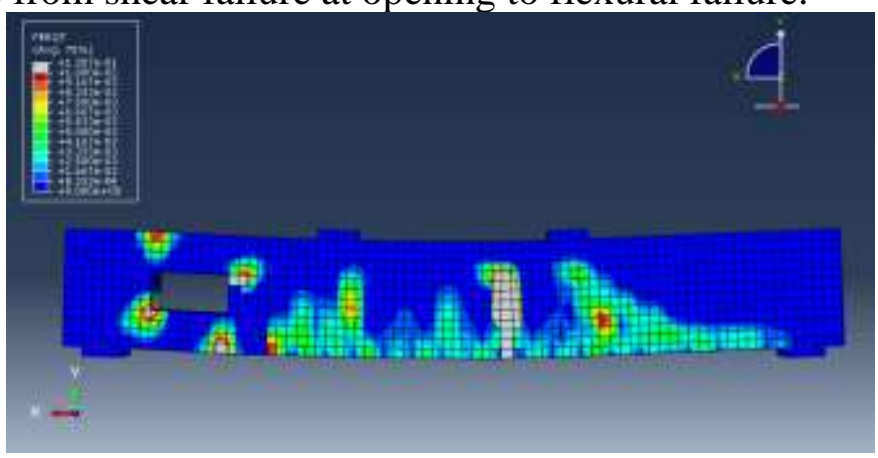

(B2-T10)

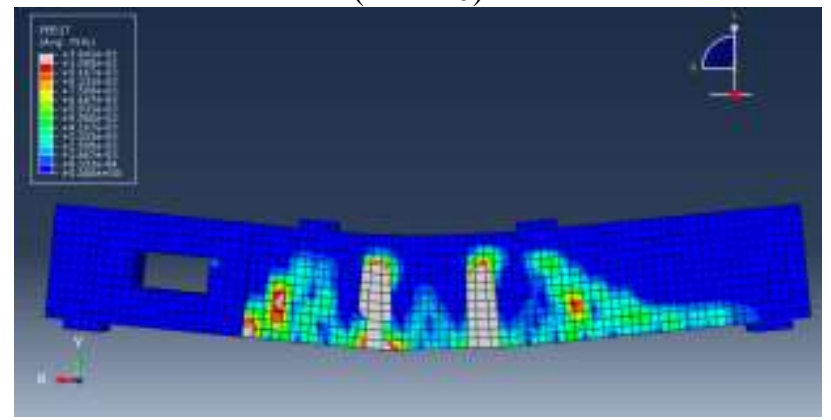

(B2-T20) 

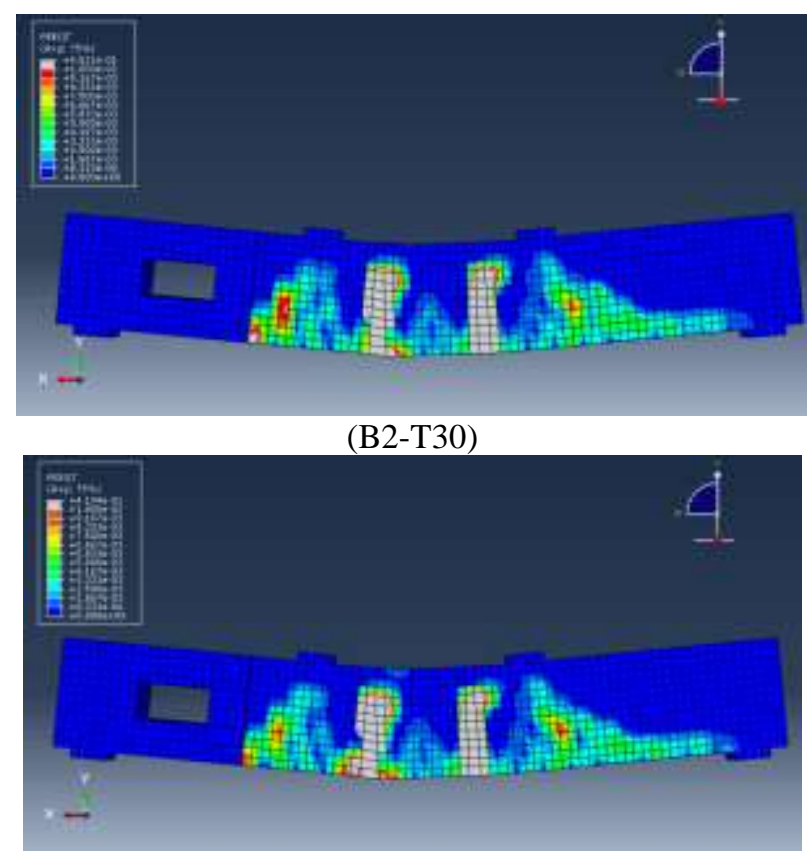

(B2-T40)

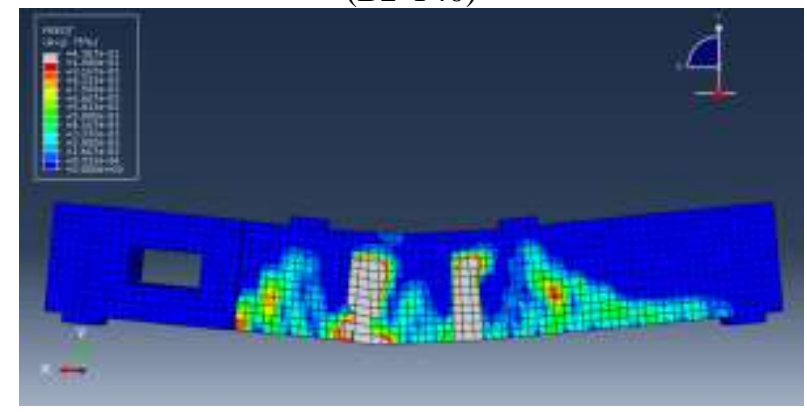

(B2-T50)

Figure 24 Failure mode for strengthening beam with opening (B2) with variable thickness FEM.

\section{Strengthened beam B2 (Group 3)}

The beam (B2) with opening strengthened by UHP-FRC plates with constant thicknesses $20 \mathrm{~mm}$ and variable width (50, 70 and100) $\mathrm{mm}$ on both sides of the RC beam around the opening. For the specimen (B2-W50), the failure occurred due to shear failure at corner of the opening, as shown in Figure 25.

For the specimen (B2-W70) and (B2-W70), the failure occurred due to flexure failure of the beam span, as shown in Figure 25. The use of UHP-FRC plate changing the failure mode from shear failure at opening to flexural failure.



(B2-W50) 


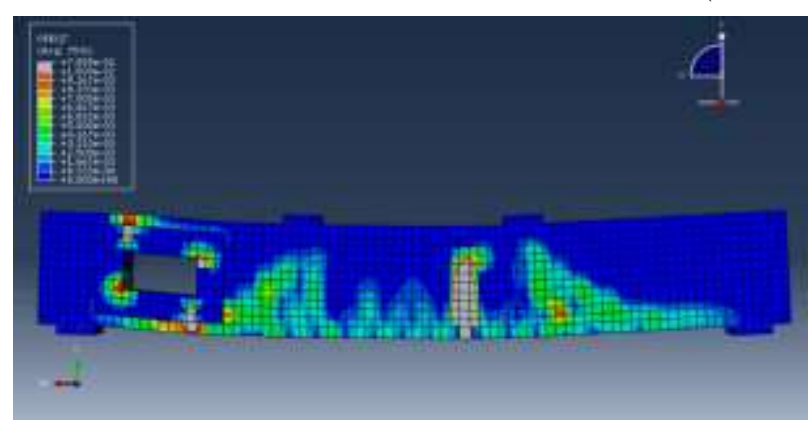

(B2-W70)

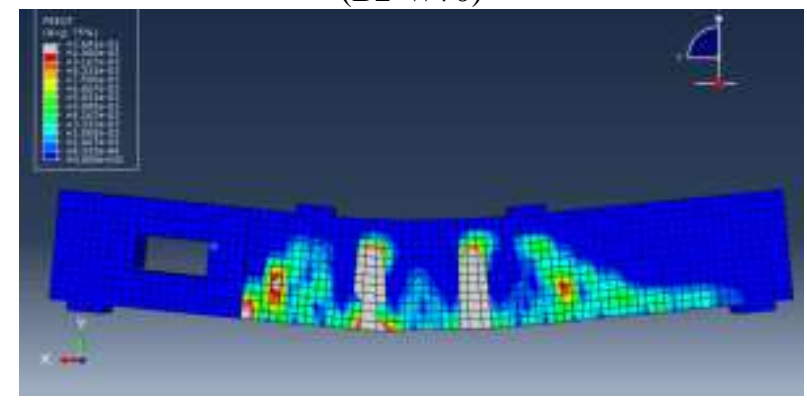

(B2-W100)

Figure 25 Failure mode for strengthening beam with opening (B2) with variable width FEM.

\section{CONCLUSION}

The following findings can be made from the observations of the investigation:

1. The presence of opening in shear zone decrease the ultimate load as well as deflection.

2. The opening of the web beams at shear zone changing the failure mode from flexure to shear failure.

3. The strengthening of RC beam with opening using UHP-FRC plate significantly enhance the ultimate load and ductility.

4. The use of UHP-FRC plate with thickness $10 \mathrm{~mm}$ increase the ultimate loads about $52.99 \%$. Also, the use of plates with thickness $20 \mathrm{~mm}$ increases the ultimate loads about $62.81 \%$, while the use of plates thickness 30,40 and 50 could not provide any enhancement in the ultimate loads and deflections.

5. The use of UHP-FRC plate with thickness $20 \mathrm{~mm}$ and variable width 50,70 and $100 \mathrm{~mm}$ increases the ultimate loads from $23.91 \%$ to $62.81 \%$.

6. The use of UHP-FRC plate changing the failure mode from shear failure at opening to flexural failure.

\section{REFERENCES}

[1] M. A. Mansur, "Effect of Openings on the Behaviour and Strength of R / C Beams in Shear," vol. 20, pp. 4-13.

[2] A. A. Ahmed, S. Naganathan, K. Nasharuddin, and M. M. Fayyadh, "Structure- Technical Note Repair effectiveness of CFRP and steel plates in RC beams with web opening: effect of plate thickness," vol. 13, no. 2, 2015.

[3] "ALFEEHAN, Ashraf A. Strengthening of RC beams by external steel plate using mechanical connection technique. Journal of Engineering and Sustainable Development, 2014, 18.2: 202-215.."

[4] H. Tahsiri, O. Sedehi, A. Khaloo, and E. M. Raisi, "Experimental study of RC jacketed and CFRP strengthened RC beams," Constr. Build. Mater., vol. 95, pp. 476-485, 2015, doi: 10.1016/j.conbuildmat.2015.07.161. 
NUMERICAL STUDY ON THE BEHAVIOR OF RC BEAMS WITH OPENINGS STRENGTHENED WITH ULTRA HIGH PERFORMANCE - FIBER REINFORCED CONCRETE (UHP-FRC)

[5] F. J. Alaee, B. L. Karihaloo, and F. Asce, "Retrofitting of Reinforced Concrete Beams with CARDIFRC," no. August, pp. 174-186, 2003.

[6] K. Habel, M. Viviani, E. Denarié, and E. Brühwiler, "Development of the mechanical properties of an Ultra-High Performance Fiber Reinforced Concrete ( UHPFRC )," vol. 36, pp. 1362-1370, 2006, doi: 10.1016/j.cemconres.2006.03.009.

[7] S. Kang, Y. Lee, Y. Park, and J. Kim, "Tensile fracture properties of an Ultra High Performance Fiber Reinforced Concrete ( UHPFRC ) with steel fiber," Compos. Struct., vol. 92, no. 1, pp. 61-71, 2010, doi: 10.1016/j.compstruct.2009.06.012.

[8] M. Xu and K. Wille, "Fracture Energy of UHP-FRC under Direct Tensile Loading Applied at Low Strain Rates," Compos. Part B, 2015, doi: 10.1016/j.compositesb.2015.05.031.

[9] D. Y. Yoo, N. Banthia, S. W. Kim, and Y. S. Yoon, "Response of ultra-high-performance fiberreinforced concrete beams with continuous steel reinforcement subjected to low-velocity impact loading," Compos. Struct., vol. 126, pp. 233-245, 2015, doi: 10.1016/j.compstruct.2015.02.058.

[10] P. R. Prem, B. H. Bharatkumar, and N. R. Iyer, "Influence of curing regimes on compressive strength of ultra high performance concrete," Sadhana - Acad. Proc. Eng. Sci., vol. 38, no. 6, pp. 14211431, 2013, doi: 10.1007/s12046-013-0159-8.

[11] P. R. Prem, A. R. Murthy, G. Ramesh, B. H. Bharatkumar, and N. R. Iyer, "Flexural Behaviour of Damaged RC Beams Strengthened with Ultra High Performance Concrete," doi: 10.1007/978-81322-2187-6.

[12] A. A. Bahraq, M. A. Al-Osta, S. Ahmad, M. M. Al-Zahrani, S. O. Al-Dulaijan, and M. K. Rahman, "Experimental and Numerical Investigation of Shear Behavior of RC Beams Strengthened by Ultra-High Performance Concrete," Int. J. Concr. Struct. Mater., vol. 13, no. 1, 2019, doi: 10.1186/s40069-018-0330-z.

[13] A. P. Lampropoulos, S. A. Paschalis, O. T. Tsioulou, and S. E. Dritsos, "Strengthening of reinforced concrete beams using ultra high performance fibre reinforced concrete (UHPFRC)," Eng. Struct., vol. 106, pp. 370-384, 2016, doi: 10.1016/j.engstruct.2015.10.042.

[14] H. M. Tanarslan, N. Alver, R. Jahangiri, Yalçınkaya, and H. Yazıcı, "Flexural strengthening of RC beams using UHPFRC laminates: Bonding techniques and rebar addition," Constr. Build. Mater., vol. 155, pp. 45-55, 2017, doi: 10.1016/j.conbuildmat.2017.08.056.

[15] "Abaqus 6.13, Analysis User's Guide Volume III: Materials, 2015."

[16] "Saenz LP. Discussion of "Equation for the stress-strain curve of concrete" by DesayiP, Krishnan S". ACI J 1964;61:1229-35."

[17] A. Hillerborg, "Rilem Technical Committees The theoretical basis of amethod to determine thr fracture energy GF of concrete," pp. 291-296.

[18] T. Jankowiak and T. Lodygowski, "Identification of parameters of concrete damage plasticity constitutive model," Found. Civ. Environ. ..., no. 6, pp. 53-69, 2005, [Online]. Available: http://www.ikb.poznan.pl/fcee/2005.06/full/fcee_2005-06_053-

069_identification_of_parameters_of_concrete.pdf.

[19] Z.-H. Lu and Y.-G. Zhao, "Empirical Stress-Strain Model for Unconfined High-Strength Concrete under Uniaxial Compression," J. Mater. Civ. Eng., vol. 22, no. 11, pp. 1181-1186, 2010, doi: 10.1061/(asce)mt.1943-5533.0000095. 
[20] M. Asadi, "E Xperimental Test and F Inite E Lement M Odelling of Pedestrian," Test, no. Figure 1, p. 60876, 2010.

[21] G. H. Mahmud, Z. Yang, and A. M. T. Hassan, "Experimental and numerical studies of size effects of Ultra High Performance Steel Fibre Reinforced Concrete (UHPFRC) beams," Constr. Build. Mater., vol. 48, no. November 2013, pp. 1027-1034, 2013, doi: 10.1016/j.conbuildmat.2013.07.061.

[22] “AFGC, Interim Recommendations, Ultra High Performance Fibre Reinforced Concretes; 2013." [23] M. A. Al-osta, M. N. Isa, M. H. Baluch, and M. K. Rahman, "Flexural behavior of reinforced concrete beams strengthened with ultra-high performance fiber reinforced concrete," Constr. Build. Mater., vol. 134, pp. 279-296, 2017, doi: 10.1016/j.conbuildmat.2016.12.094.

[24] "Instructions for use flexural behavior of reinforced concrete beams repaired with ultra-high performance fiber reinforced concrete."

[25] Z. G. Guo, S. Y. Cao, W. M. Sun, and X. Y. Lin, "experimental study on bond stress-slip behaviour between frp sheets and concrete," no. Bbfs, pp. 77-84, 2005.

[26] X. Z. Lu, J. G. Teng, L. P. Ye, and J. J. Jiang, "Bond - slip models for FRP sheets / plates bonded to concrete," vol. 27, pp. 920-937, 2005, doi: 10.1016/j.engstruct.2005.01.014.

[27] "JCI. Technical report on continuos fibre reinforced concrete. JCI TC952 on continuos reinforced concrete; 1998. p. 116-24."

[28] "JCI. Technical report on retrofit technology for concrete structures. Technical committee on retrofitting technology for concrete structures; 2003. p. 79-97."

[29] M. A. Sakr, "Finite element modeling of debonding mechanisms in carbon fiber reinforced polymer-strengthened reinforced concrete continuous beams," no. January 2017, pp. 1002-1012, 2018, doi: 10.1002/suco.201700011.

[30] "Hibbitt, Karlsson, and Sorensen, Inc. ABAQUS Theory manual, User manual and Example Manual, Version 6.7. Providence, RI; 2000." 